\title{
Heinrich Kramer/Institoris and the Czech Lands. With a Special Focus on the Activities of Institoris in Olomouc in 1499-1505
}

Petr Kreuz

Prague City Archives

\begin{abstract}
In the last years of his life the author of the Hammer of Witches (Malleus Maleficarum), the Black (Dominican) friar Heinrich Kramer-Institoris held the office of papal inquisitor for the Bohemian (Czech) Lands. This period of his life is closely connected with his stay in the Olomouc diocese, specifically in the city of Olomouc (germ. Olmütz). Institoris was installed as inquisitor for the Bohemian Lands already in January 1499 by Pope Alexander VI, evidently at the instigation of the bishop of Olomouc Stanislav (Stanislaus) Thurzo. Institoris held the aforementioned office from 1499 until the end of his lifetime. The date of his death is traditionally quoted as the year 1505 .
\end{abstract}

\section{Keywords}

Heinrich Kramer/Institoris, Olomouc, Unity of Brethren, inquisitor, Konrad Baumgarten, book printing

\section{Contact address}

Doc. PhDr. Petr Kreuz, Dr., Archiv hlavního města Prahy, Archivní 6, 14900 Praha 4, Czech Republic e-mail: Petr.Kreuz@praha.eu

There has been, if not intensive, at least relatively thorough interest within Czech linguistic Church historiograhy in the twentieth century to Institoris' activities in Olomouc. The focus has been initially on his tractates against the Bohemian (Moravian) Brethren Clypeus and Adversus as well as to his public disputes with representatives of the (then de iure illegal) Unity of Bohemian (Moravian) Brethren. 
The Inquisitorial and literary activities of Institoris were dealt at length for the first time prior to the Great War (WWI) in an extensive specialised article by the Catholic Church historian Antonín Kubíček (1864-1924). ${ }^{1}$ He interpreted his terms as inquisitor for the Bohemian Lands and his arrival to Olomouc as a reaction by Pope Alexander VI to the request presented by the new bishop of Olomouc Stanislav I Thurzo, who was involved as of his accession to the see of the bishopric in suppressing the Unity of Bohemian Brethren. ${ }^{2}$ As far as Institoris' activities in Czech Lands are concerned, Kubíček relied first of all upon the tractates Clypeus ${ }^{3}$ and Adversus, ${ }^{4}$ jointly published in print in two editions in Olomouc in the years 1501 and $1502 .{ }^{5}$ One interesting feature should be kept in mind, namely that Kubíček recorded Institoris as the author ${ }^{6}$ of the Malleus Maleficarum in numerous editions and even mentioned the "witches bull" Summis desiderantes affectibus of Pope Innocent VIII from 5 December $1484,{ }^{7}$ but he did not further develop these facts. ${ }^{8}$ The main part of his article provides a thorough historical and theological commentary on the tractates Clypeus and Adversus.?

${ }^{1}$ Antonín Kubíček, “Jindřich Institoris, papežský inkvizitor v Čechách a na Moravě” \{Henry Institoris, a Papal Inquisitor in Bohemia and Moravia\}, Časopis katolického duchovenstva 63 (1902): 20-26, 115-120, 222-226, 320-325, 372-378, 491-500 and 521-525.

${ }^{2}$ Kubíček, "Jindřich Institoris," 20-22.

${ }^{3}$ Heinricus Institoris, Sancte Romane ecclesie fidei defensionis clypeum adversus waldensium seu pickardorum heresim... (Olomouc: Konrad Baumgarten 1501), 1. ed. (2. ed., Olomouc: Konrad Baumgarten 1502) (further only Clypeus).

${ }^{4}$ Henricus [!] Institoris, Adversus pickardorum waldensium in sanctam romanam ecclesiam horrendam blasphemiam, apocalypticam meretricem illam appellantium, opusculum..., (Olomouc: Konrad Baumgarten 1501), 1. ed. (2. ed., Olomouc: Konrad Baumgarten 1502) (further only Adversus). In print from the year 1501, (1. ed.) is the second tractate on fol. $95 \mathrm{r}-128 \mathrm{r}$.

${ }^{5}$ Kubíček, "Jindřich Institoris," 24. - Print from 1501, further also Clypeus-print 1501, the 2. edition from 1502 as Clypeus-print 1502.

${ }^{6}$ It is indisputably remarkable that Kubíček characterizes Malleus Maleficarum only as Institoris' work Kubíček, "Jindřich Institoris," 24, note 9, and 373-374, n. 3.

${ }^{7}$ Kubíček "Jindřich Institoris," 119, n. 7.

${ }^{8}$ It is worth mentioning that the first modern Czech encyclopedia, Ottův slovník naučný, paid attention to Institoris in a concise heading mainly as a critic of the Unity of Brethren at the time of his activities in Olomouc and not as the coauthor (!) of the Malleus Maleficarum - Včk [= Jaroslav Vlček], "Institoris, Henricus," in Ottiov slovnik naučný \{Otto’s Encyclopedic Dictionary)\}, 12th volume (Praha: J. Otto 1897), 674. - Similarly as the author of the heading in the Ottův slovník naučný, is the reference to Institoris in Josef Jireček, Rukovět $k$ dějinám literatury české do konce XVIII. věku \{Handbook of the History of Czech Literature until the End of the XVIII century\}, vol. I, (Praha: Nákladem B. Tempského 1875), 297-298.

9 The first modern Bohemian researcher to pay attention to the tractates Clypeus and Adversus was a Bohemian historian of German origin Nicolaus Adaukt Voigt (1733-1787). He even edited two introductory texts printed in Clypeus, this being the bull of Pope Alexander VI from 31 January 1499 and a papal brief (breve) from 5 February 1500 - Adauctus Voigt, Acta litteraria Bohemiae et Moraviae, vol. II, (Prag: Wolfgangi Gerle 1783), 410-418. - The print of Olomouc from 1501 was also introduced into the history of Czech literature with its full detreatiseion already by Josef Dobrovský, Böhmische und Mährische Literatur auf das Jahr 1780 (Prag 1780), 29-32. - An enumeration of other older Czech publications containing mention of Institoris is furnished by Kubíček, "Jindřich Institoris", 22, n. 6. 
The outstanding Czech Evangelical Church historian Amedeo Molnár (1923-1990) returned to the above-mentioned, in Olomouc edited, tractate of Institoris in a specialised study at the beginning of the 1980s. ${ }^{10}$ According to him the tractates Clypeus and Adversus bear witness to the fact, that Institoris "was conscious of the uniqueness of the Czech milieu marked by the consequences of the Hussite revolution" and "by the real existence of two creeds" ${ }^{11}$ On the basis of the state of research of this time, Molnár attempted to depict Institoris' knowledge of the Bohemian and Moravian (esp. Czech) intellectual and social milieu, his possible personal connections and contacts in the Bohemian Lands and the impact of his literary activities in Olomouc. ${ }^{12}$

A fundamental contribution to the knowledge of the activities developed by Institoris in the Bohemian Lands is due to the church historian Vojtěch Sokol (1883-1951) in his post mortem issued monograph study about the leading minister and theologian of the Unity of Brethren Vavřinec Krasonický, known as Lorek. ${ }^{13}$ Sokol paid considerable attention to the circumstances, contents and turn of the theological dispute between Institoris on the one hand and two leaders of the Unity of Bohemian Brethren Krasonický and Tůma Přeloučský on the other. The said dispute took place in Olomouc shortly after the middle of the year $1500 .{ }^{14}$ Sokol based his assertions, in describing the debate, not only on Institoris' detreatiseion contained in the tractate Clypeus, but also on dispersed and fragmentary contemporary sources of Brethren origin. ${ }^{15}$

The prints of the tractates Clypeus and Adversus, along with other prints related to Institoris, were described in a materially very valuable study devoted to the activities of the German printer Konrad Baumgarten in Olomouc by a specialist in the history of the book Jaroslav Vobr (1939-2013). ${ }^{16}$ The same scholar spent, as early as the beginning of the 1970s, his time in studying the announcement of the first edition of the print of the tractates Clypeus and Adversus printed on the reverse side of the indulgence deed. ${ }^{17}$

${ }^{10}$ Amedeo Molnár, "Protivaldenská polemika na úsvitu 16. století \{Antiwaldensian Polemics on the Eve of the Sixteenth Century\}", Historická Olomouc a její soućasné problémy 3 (1980): 153-174. Cf. also Amedeo Molnár, "Autour des polèmiques anti-vaudoises du début du XVI siécle", in I Valdesi e l'Europa. Collana della società di studi Valdesi 9 (1982): 116-136.

${ }^{11}$ Molnár, "Protivaldenská polemika," 153.

${ }^{12}$ Molnár, "Protivaldenská polemika," 159-162.

${ }^{13}$ Vojtěch Sokol, "Vavřinec Krasonický," in Praga mystica. Z dějin české reformace \{From the History of the Reformation in Bohemia\}, edited by Amedeo Molnár (Praha: Ústřední církevní nakladatelství 1984), 51-108.

${ }^{14}$ Sokol, "Vavřinec Krasonický," 63.

15 Sokol, "Vavřinec Krasonický," 63-66 and 97-101.

${ }^{16}$ Jaroslav Vobr, "Př́spěvek k činnosti Konrada Baumgartena v Olomouci 1500-1502" \{A Contribution to the Activities of Konrad Baumgarten in Olomouc 1500-1502\}, Problematika historických a vzácných knižních fondü Čech, Moravy a Slezska \{Problems Connected with the Historical and Rare Book Collections in Bohemia, Moravia and Silesia\} 1995 (Brno: Sdružení knihoven České republiky - Olomouc: Státní vědecká knihovna 1996), 10-16.

${ }_{17}$ Jaroslav Vobr, "Neznámá olomoucká odpustková listina z roku 1501” \{The Unknown Indulgence Deed of Olomouc from 1501\}, in Docentu PhDr. Františku Horákovi k šedesátinám. Sborník prací a personální bibliografie \{On the Sixtieth Birthday of Prof. PhDr. František Horák. Collection of Work and a Personal Bibliography\}. Edited by Blahoslav Kovár (Praha: Katedra knihovnictví a vědeckých informací Fakulty 
The art historian Ivo Hlobil (born 1942) devoted himself, in the middle of the 1970s, to the book wood engravings in the print of the tractates Clypeus and Adversus. He also paid attention to certain broader connections of Institoris' activities developed in the fields of art and culture. ${ }^{18}$

The last decade witnessed some very important ascertainments about Institoris' activities and literary work in Olomouc due to research carried out by the Israeli historian Tamar Herzig. T. Herzig published the results of her research - after several preparatory studies ${ }^{19}$ - in an extensive monograph, which was issued in $2013 .{ }^{20}$ The main object of her interest became the tractate (pamphlet) Stigmifere virginis Lucie de Narnia aliarumque spiritualium personarum feminei sexus facta admiracione digna. This pamphlet, whose scope was eight non-paginated sheets, appeared in print in Olomouc in September 1501 at the aforementioned Baumgarten's printer. It dealt with the mystical experiences of three Italian "holy" women of that time, Lucy Brocadelli from Narni (1476-1544), Stephana de Quinzanis (1457-1530) and Colomba of Rieti (1467-1501), ${ }^{21}$ later all of them beatified. Herzig proved beyond a doubt that the main author of this pamphlet was Institoris, ${ }^{22}$ who was previously considered only its editor. ${ }^{23}$ The black friar Jacob Johannes Streller from the

sociálních věd a publicistiky University Karlovy and Státní knihovna ČSR 1971), 23-32. - Attention was drawn for the first time to the aforementioned announcement by the German incunabolist K. Schottenloher - Karl Schottenloher, Eine Bücheranzeige des Olmützer Buchdruckers Konrad Baumgarten aus dem Jahre 1501 (München: Verlag der Münchner Drucke 1927).

${ }^{18}$ Ivo Hlobil, "Nejstarší olomoucké knižní dřevořezy. Knižní dřevořezy olomoucké diecéze mezi léty 1499-1505 a jejich protireformační význam" \{The Oldest Book Wood Engravings from Olomouc. The Wood Engravings of the Diocese of Olomouc Between the Years 1499-1505 and their Importance within the Context of the Counter-Reformation\}, Uméní 24 (1976): 327-358.

19 Tamar Herzig, "Witches, Saints, and Heretics. Heinrich Kramer's Ties with Italian Women Mystics", Magic, Ritual, and Witchcraft 1, no. 1 (2006): 24-55; Tamar Herzig, "Heinrich Kramer e la caccia alle streghe in Italia, in "Non lasciar vivere la malefica". Le streghe nei trattati e nei processi (secoli XIV-XVII), edited by Dinora Corsi and Matteo Duni. (Florence: Florence University Press 2008) 167-196; Tamar Herzig, "Italian Holy Women against Bohemian Heretics. Catherine of Siena and 'the Second Catherines' in the Kingdom of Bohemia", in Catherine of Siena. The Creation of a Cult, edited by Jeffrey Hamburger - Gabriela Signori. (Turnhout: Brepouls 2013), 315-338.

${ }^{20}$ Tamar Herzig, Christ Transformed into a Virgin Woman. Lucia Brocadelli, Heinrich Institoris and the Defense of Faith (Roma: Edizioni di Storia e Letteratura 2013).

${ }^{21}$ Herzig, Christ, xi.

${ }^{22}$ Herzig, Christ, 158-159. - T. Herzig confirmed first of all the existence of numerous textual and formal congruences between Stigmifere and the tractate Clypeus by Institoris, which appeared for the first time in the same year and at the same printer established in Olomouc. It seems relevant to remark that the researcher in book history V. Dokoupil turned his attention, at the beginning of the 1970s, to textual congruences between Stigmifere and Clypeus as concerns depicting the miracles performed by Lucy Brocadelli - Vladislav Dokoupil, "Neznámý tisk olomouckého tiskaře Konrada Baumgartena" \{An unknown print of the printer Konrad Baumgarten of Olomouc\}, in Docentu PhDr. Františku Horákovi, 14-22, esp. 18-22. Dokoupil stated, even in this connection, that Stigmifere may be "some sort of separate copy" taken from Clypeus.

${ }^{23}$ Vobr, "Př́spěvek" 11, n. 2. - The possibility of Institoris being the author of Stigmifere was implicitly alluded to by V. Dokoupil, "Neznámý tisk", 21 (compare above n. 22), whose knowledge extended only to the copy of Stigmifere deposited in the Austrian National Library (Österreichische Nationalbibliothek) 
monastery of St. Adalbert in Breslau (cz. Vratislav, pol. Wrocław) was the mere coauthor of the said pamphlet and only took part in its final editing. ${ }^{24}$ The importance of the findings of T. Herzig lies mainly in the fact, that Institoris describes Lucy Brocadelli in his pamphlet as an incarnation of Christ. This fascination with embodied feminine mysticism serves to call into question the prevailing view of Institoris' enmity towards women, this being a product of the traditional interpretation of the Malleus Maleficarum as arguably the most misogynist work from the end of the Middle Ages and the Early Modern Period. ${ }^{25}$

Our knowledge of Institoris' activities in regard to the Bohemian Lands was extended quite recently thanks to the historian and outstanding researcher in the field of the history of the book Kamil Boldan (born in 1966) in his monograph on late Medieval one-sheet prints from Bohemia and Moravia of the Jagiellonian age. ${ }^{26}$ Boldan pointed out - apart from other sources - on the basis of newly discovered formularies of indulgence deeds the fact that Institoris played a rather important role in the history of early Bohemian and Moravian book printing, which was not limited to only Baumgarten's printing workshop in Olomouc. ${ }^{27}$

The historian Petr Hlaváček (born in 1974) found, when enjoying the luck of a prepared scholar during his research into Franciscan history in the Bohemian Lands, ${ }^{28}$ an account of Heinrich Institoris' death place in a Bohemian Franciscan province of the time. ${ }^{29} \mathrm{He}$ also published an independent study, in which he tried to place Institoris' activities into the broader context of the religious history of Central and East Central Europe at the end of the Middle Ages. ${ }^{30}$

in Vienna, which he considered unique and which was inaccesible for him in the beginning of the 1970s. Dokoupil did not know about the copy of Stigmifere deposited in the University library in Warsaw, which was later used by T. Herzig.

${ }^{24}$ Herzig, Christ, 157-158.

${ }^{25}$ Herzig, Christ, xii: "The Malleus, as is well known, is, arguably, the most misogynist work written in the Premodern era. And yet, the Stigmifere's fascination with embodied female mysticism goes beyond simple categorizations, and calls for a reevaluation and a contextualization of Institoris's attitude toward women." - The most detailed contribution about Institoris' psychology is by Günter Jerouschek, "Heinrich Kramer (Institoris) - Zur Psychologie des Hexenjägers. Überlegungen zur Herkunft des Messers, mit dem der Mord begangen wurde", in Gewalt und ihre Legitimation im Mittelalter, edited by Günther Mensching (Würzburg: Königshausen und Neumann 2003), 113-137. See too Heinrich Kramer (Institoris), Der Hexenhammer. Malleus Maleficarum. Neu aus dem Lateinischen übertragen von Wolfgang Behringer, Günter Jerouschek und Werner Tschacher. Herausgegeben und eingeleitet von Günter Jerouschek und Wolfgang Behringer, 2. ed., (München: Deutscher Taschenbuch-Verlag (dtv) 2001), 78-81.

${ }^{26}$ Kamil Boldan, Úrední jednolistové tisky jagellonského věku \{Official One-sheet Prints of the Jagellonian Age\} (Praha: Národní knihovna České republiky 2016).

${ }^{27}$ Boldan, Úrední jednolistové tisky, 20-27, 72-73, 81-84 and 87-88.

${ }^{28}$ Petr Hlaváček, Die böhmischen Franziskaner im ausgehenden Mittelalter. Studien zur Kirchen- und Kulturgeschichte Ostmitteleuropas (Stuttgart: Franz Steiner Verlag 2011).

${ }^{29}$ Petr Hlaváček, Die böhmischen Franziskaner, 114-115.

${ }^{30}$ Petr Hlaváček, "Inkvizitor Heinrich Institoris († 1505) a jeho působení v českých zemích" \{The Inquisitor Heinrich Institoris $(\dagger 1505)$ and his Activities in the Bohemian Lands $\}$, Lutheranus. Studie a texty $k$ teologii a dějinám luterské reformace \{Studies and Texts Concerning the Theology and History of the Lutheran 
A certain analogy to the aforementioned biographical study by V. Sokol ${ }^{31}$ is the recently published monograph about the life of Institoris' second Brethren opponent in the Olomouc dispute, the theologian Tůma Přeloučský, writtten by the historian Karolína Justová, born Petrasová (born in 1973). ${ }^{32}$

The first known contact with the Bohemian Lands on the part of Heinrich Institoris, who was born around 1430 in Alsatian Sélestat (Schlettstadt), ${ }^{33}$ can be registered in connection with his second stay in Rome around $1460 .{ }^{34}$ In the second book of Malleus Maleficarum, Institoris describes how he met by chance in the eternal city, at the time of the pontificate of Pope Pius II (1405-1464, pont. 1458-1464), still not an inquisitor, one Bohemian and they had a chat over a shared meal. The Bohemian was from Tachov (Dachow, ${ }^{35}$ Bohemus quidam de dachono oppido $\left.{ }^{3 \sigma}\right) .{ }^{37}$ This man from Bohemia had with him his only son, sitting

Reformation\} 5 (2015): 67-82. Recently see the German version of the same study Petr Hlaváček, “'Apostolus sed non Christi." Der Dominikanerinquisitor Heinrich Institoris (†1505) und seine Tätigkeit in den böhmischen Ländern," in Religious Violence, Confessional Conflicts and Models for Violence Prevention in Central Europe (15th-18th Centuries) - Religiöse Gewalt, konfessionelle Konflikte und Modelle von Gewaltprävention in Mitteleuropa (15.-18. Jahrhundert), edited by Joachim Bahlcke, Kateřina Bobková-Valentová and Jiří Mikulec (Praha: Historický ústav AV ČR - Stuttgart: Universität Stuttgart 2017) 39-52.

${ }^{31}$ See above n. 13.

32 Karolína Justová, Tưma Přeloučský. Muž znamenitý, který jiné prevyšoval \{Tůma Přeloučský. An Outstanding Man, Who Surpassed the Others\} (Praha: Univerzita Karlova v Praze, Pedagogická fakulta 2011). As concerns Institoris and the the Olomouc dispute, see particularly Justová, Tưma Přeloučský, 73-78. Compare also Karolina Petrasová [= Justová], “Tůma Přeloučský. Osobnost a dílo zapomenutého biskupa v kontextu nejstarších dějin jednoty bratrské” \{Tůma Přeloučský. The Personality and Work of a Forgotten Bishop in the Context of the Oldest History of the Unity of Brethren\}. (Thesis presented at the Department of History and Didactics of the Faculty of Education of Charles University Prague) (Praha 2006), 4-15 and 60-65.

${ }^{33}$ See e. g. Herzig, Christ, 3.

${ }^{34}$ Concerning this date Joseph Hansen, Quellen und Untersuchungen zur Geschichte des Hexenwahns und der Hexenverfolgung im Mittelalter (Bonn: Georgi 1901), 381. In accordance with Hansen as well Peter Segl, "Heinrich Institoris, Persönlichkeit und literarisches Werk", in Der Hexenhammer. Entstehung und Umfeld des Malleus maleficarum von 1487, edited by Peter Segl (Köln and Wien: Böhlau 1988), 103-126, esp. 104. ${ }^{35}$ It is not quite clear why Hlaváček, "Inkvizitor", 72, states that the named priest was from Kadaň (germ. Kaaden). (Cf. Hlaváček, "Apostolus", 42.) The name of this town appears to my knowledge in this connection only with B. Šindelář (Bedřich Šindelář, Hon na čarodějnice. Západni a středni Evropa v 16.-17. století \{The Witch Hunt. Western and Central Europe in the Sixteenth-Seventeenth Centuries\} (Praha: Svoboda 1986), 37 and 234, n. 53, with reference to the older translation of Malleus Maleficarum into German provided at the beginning of the twentieth century by the linguist J. W. R. Schmidt) and afterwards in a Czech "rendering" of Malleus Maleficacum, provided recently on the basis of the translation into English by Montague Summers from the 1920s by "the mystery expert" J. Lenková-Malleus Maleficarum. Kladivo na čarodějnice \{The Hammer of Witches\}, translated by Jitka Lenková (Praha: Otakar II. 2000), 307. As for this "translation" see Petr Kreuz, "Dva překlady Kladiva na čarodějnice” \{Two Translations of the Hammer of Witches\}, Listy filologické 125 (2002): 139-149.

${ }^{36}$ See the second edition of the Hammer of Witches (Speyer 1490): http://diglib.hab.de/inkunabeln/151quod-2f-1/start.htm?image $=00100$ (vidimus 12. 7. 2017).

37 Tachov (germ. Tachau) in West Bohemia was, since its origin in the second half of the thirteenth century until 1945, an ethnically uniform German town. The word Bohemus is consequently in the given connection introduced as a designation of the country of origin and not as a designation of the ethnic make-up. 
beside him at the table. The son was a secular priest and was supposed to be possessed by demons. The named Bohemian had travelled with much effort and expense to Rome to make his son submit to an exorcism. After having observed the son and taking him with him, Institoris started to object that he may not be possessed, but be suffering from some disease. The son told him allegedly that his being, possessed by the demon, was caused by a witch, a woman he had reprimanded at the parsonage. Institoris describes further that he had not believed the priest at the beginning, that he was possessed, because he had not lost his mind as was usually the case with the possessed. The priest answered that the demon deprived him of his mind only in divine matters and in holy places. First of all he disturbed allegedly his sermons by putting in his mouth words which give rise to displeasure by the people, in spite of the fact he had been a popular preacher in the past. Institoris depicts further the imaginary dramatic course of the exorcisms. He repeats that the concerned priest appeared as possessed only during the exorcisms, not manifesting after they finished the least symptom of possession at all. ${ }^{38}$

In close proximity to the Bohemian Lands and moreover in one of the lands of the Crown of Bohemia, in Lusatia, ${ }^{39}$ the presence of Institoris is attested to only at the end of the 1460s, when Pope Paul II (1417-1471, pont. 1464-1471) declared in 1467 a crusade against the "heretic" King of Bohemia George of Podebrady (1420-1471, King in 1458-1471). The papal diplomat Rudolf of Rüdesheim (cca 1402-1482) was appointed the general commissioner of this crusade, who became in January 1468 Bishop of Vratislav (germ. Breslau, pol. Wrocław). It was Rudolf who appointed Institoris in October 1467 to the post of secretary charged with indulgences and as the preacher for Lusatia and the land of Meißen. ${ }^{40}$ Institoris' task consisted in agitation to provide financial support to the declared crusade. ${ }^{41}$ Institoris arrived, however, at this field of activity only in August $1469 .{ }^{42}$

Two copies of indulgence deeds, printed by Institoris in Strasbourg at the latest at the end of the year 1469, were discovered in 2012 and 2013 at almost the same time. The mentioned one-sheet bohemical prints were found in the City Archives in Chemnitz and in the University Library in Leipzig. ${ }^{43}$ The found prints of indulgence deeds are of importance, among other things, because they originate from a very early phase of printing and are one of the oldest bohemical prints at all. They are also an important original

${ }^{38} \mathrm{http}$ ://diglib.hab.de/inkunabeln/151-quod-2f-1/start.htm?image=00100, http://diglib.hab.de/ inkunabeln/151-quod-2f-1/start.htm?image=00101; Kramer (Institoris), Der Hexenhammer, 447-449; André Schnyder, Malleus Maleficarum von Heinrich Institoris (alias Kramer), unter Mithilfe Jakob Sprengers aufgrund der dämonologischen Tradition zusammengestellt. Kommentar zur Wiedergabe des Erstdrucks von 1487 (Göppingen: Kümmerle 1993), 185-186. Cf. also Šindelář, Hon na čarodějnice, 37.

${ }^{39}$ Herzig, Christ, 7, writes in this connection inaccurately about "his first mission in Bohemia". I consider it very improbable that Institoris should have come to the Bohemian Lands, and even less probable to actual Bohemia (= the Kingdom of Bohemia). In any case it cannot be proven.

${ }^{40}$ Schnyder, Malleus Maleficarum, 34 (n. 4).

${ }^{41}$ Schnyder, Malleus Maleficarum, 26 and 34 (n. 4); Boldan, Úredni jednolistové tisky, 25-26. Cf. also Hlaváček "Inkvizitor," 72.

${ }^{42}$ Herzig, Christ, 7.

${ }^{43}$ Boldan, Úrední jednolistové tisky, 24-27. 
source of knowledge about the activities of Heinrich Institoris at the turn of the 1470s. This source has been until now known from later copies only (duplicates). ${ }^{44}$ Institoris is in the formulary of the deed designataed as " $m$ [a]g[iste]r heinricus sletstater, ordinis $p$ [re] dicator [um]". ${ }^{45}$ Institoris abolished the interdict in Leipzig because of the alleged presence of "Bohemorum fautorumque hereticorum" in this town in January 1470 as a commissioner of the papal legate. ${ }^{46}$

The financial return of the above-mentioned indulgence campaign was far from dazzling. ${ }^{47}$ Its definitive end was brought about obviously by the death of King George of Podebrady in March 1471. Institoris probably stayed in Rome once again in $1472 .{ }^{48}$ For more than a quarter of a century the vestiges of his activities may be traced mainly in the southern and south-western part of the German Roman Empire ${ }^{49}$ as well as in Italy. ${ }^{50}$ Institoris did not apparently come at this time in close contact with the Bohemian Lands or with the other lands of the Crown of Bohemia. ${ }^{51}$

In October 1491 it is possible to document Institoris' contact with the City Counsel of the German imperial city of Nuremberg, for which he elaborated instructions written in

${ }^{44}$ See below n. 45.

${ }^{45}$ For an image of a copy from the City Archives in Chemnitz see Boldan, Úrední jednolistové tisky, 21. The adressees of the fully preserved deed were the city council member Hans Neffe from Chemnitz and his wife Dorothea (Boldan, U'redni jednolistové tisky, 21 and 26). - The text of the Chemnitz indulgence deed, dated 20 February 1470 was printed already by Schnyder, Malleus Maleficarum, 35-36 (nr. 7), but only on the basis of the book by Adam Daniel Richter, Umständliche, aus zuverläßigen Nachrichten zusammengetragene Chronica der, an dem Fuße des Meißnischen Erzgebürges gelegenen, Königl. Pohln. und Churfürstl. Sächs. Stadt Chemnitz, vol. 2 (St. Annaberg: Fries/Spickermann 1754) 321. - Schnyder, Malleus Maleficarum, 35 (nr. 6) reprinted moreover a deed whose source was the same earlier printed formulary issued by Institoris with the date 15 February 1470 for a certain Caspar Seywath on the basis of the work by Valentin Ernst Löscher, Vollständige Reformations-Acta und Documenta oder Umständliche Vorstellung des Evangelischen Reformations-Wercks, 3. tomus (Leipzig: Grosse (Größische Handlung) 1729). - On the basis of this second deed it is possible to shift the terminus ad quem stated by Boldan, when Institoris surely had at his disposal the formulary of the deed, from 20 February 1470 to 15 February of the same year (cf. Boldan, Úredni jednolistové tisky, 21 and 26-27). ${ }^{46}$ Schnyder, Malleus Maleficarum, 35 (no. 5). - Hlaváček, "Inkvizitor", 72, very inexactly and without reference to a source, states, that Institoris investigated "Bohemian heretics" in 1470 in Leipzig.

${ }^{47}$ Boldan, Úrední jednolistové tisky, 26.

${ }^{48}$ Herzig, Christ, 7.

49 Schnyder, Malleus Maleficarum, 26-32; Segl, "Heinrich Institoris," 104-116; Kramer (Institoris), Der Hexenhammer, 40-69 and 88-89; Herzig, Christ, 7-80.

${ }^{50}$ Institoris' contacts with Italy and the Italian milieu in the second half of the fifteenth century are emphasized by Herzig, Christ, 3-112. See also Schnyder, Malleus Maleficarum, 26 and 28; Kramer (Institoris), Der Hexenhammer, 41-43. Cf. also Wolfgang Behringer, "Zurück in Rom. Tirol als Testgebiet des internationalen Verfolgungsspezialisten Heinrich Kramer", in Ein Fels in Brandung? Bischof Golser und der Innsbrucker Hexenprozess von 1485, edited by Andreas Exenberger (Kufstein: IMT-Verlag 2015), 55-71, esp. 58-68. ${ }^{51}$ Hlaváček, "Inkvizitor," 72, expresses the audacious supposition that Institoris "diagnosed" the pious women (beckhard), whom he investigated in Augsburg in 1480 as "followers of the Hussite heresy". Cf. also Hlaváček, "Apostolus," 42-43. - Institoris mentions later in the first sermon of his Tractatus varii "Bohemian or Hussite heresy" - Herzig, Christ, 73, incl. n. 83 and 84. 
German on how to conduct witch trials, ${ }^{52}$ the so-called Nürnberger Hexenhammer. ${ }^{53}$ The said work was an expression of Insitoris' intention to engage in witch hunts in secular courts as well. His instructions were never used, however, by the Nuremberg town council. ${ }^{54}$ The fourth edition of the Hammer of Witches was nonetheless printed in the Nuremberger printing office of Anton Koberger in 1494. The same printer was responsbile two years later for the sixth edition of the same work..$^{55}$

As late as 1493 Institoris was active as a preacher in the diocese of Salzburg. The ordersuperiors ordered him repeatedly, in November 1493 and in January 1494, to stop his preaching activities. ${ }^{56}$ He protested against his revocation in February 1494 with reference to his alleged professional and moral qualities at the general of the Dominican order, the archbishop of Salzburg Friedrich V von Schaunberg. ${ }^{57}$ Despite this, Institoris' sojourn lasted only approximately until the middle of the $1490 \mathrm{~s} .{ }^{58}$

Institoris shifted his residence again to Italy in $1495,{ }^{59}$ staying there (with only one known interruption ${ }^{60}$ ) until the beginning of the year $1499 .{ }^{61}$ He operated at that time mainly in Venice. ${ }^{62}$ Even then, in the second half of the 1490s, he was registered by Pope Alexander VI (Rodrigo Borgia, 1431-1503, pont. 1492-1503). In the summer of the year 1499, Institoris published in print in Venice the theses of his dispute held there in August 1496, ${ }^{63}$ entitled Opusculorum in errores 'Monarchie. ${ }^{64}$ The dispute consisted of a controversy with the treatise of the canon law scholar, consistorial attorney and former papal legate Antonio Roselli (1380-1466) Tractatus de potestate imperatoris ac papae (known also as Monarchia). Rosellis' treatise originated around 1440 and was distributed in print

\footnotetext{
52 Schnyder, Malleus Maleficarum, 30-31.

53 "Nürnberger Hexenhammer" von Heinrich Kramer. Faksimile der Handschrift von 1491 mit Transkription des deutschen Textes, Einleitung und Glossar, edited by Günter Jerouschek, (Hildesheim, Zürich and New York: Olms 1992).

54 “Nürnberger Hexenhammer”, VIII; Kramer (Institoris), Der Hexenhammer, 88-89.

55 Schnyder, Malleus Maleficarum, 452.

${ }^{56}$ Schnyder, Malleus Maleficarum, 31 and 60 (no. 55 and 56).

${ }^{57}$ Schnyder, Malleus Maleficarum, 31 and 60-61 (no. 57).

${ }^{58}$ In August 1495 Institoris completed in Augsburg a collection of 36 sermons on the questions of the Eucharist and transsubstantiation, which was printed (as the sixth edition of the Hammer of Witches, cf. above n. 55) in January 1496 in Nuremberg at Anton Koberger's under the title Tractatus varii cum sermonibus plurimis contra quattuor errores novissime exortos adversus divinissimum eucharistie sacramentum. Institoris designed himself in the above-mentioned print as a lector ecclesie Saltzburgensis - Herzig, Christ, 63-76; Segl, "Heinrich Institoris," 114-116; Schnyder, Malleus Maleficarum, 31 and 61 (no. 58).

${ }^{59}$ His activities in Venice are documented for November 1495 and August 1496 - Schnyder, Malleus Maleficarum, 32, 61 (no. 59) and 62 (no. 62); Herzig, Christ, 76-77.

${ }^{60}$ His sojourn in Rohr in Lower Bavaria is documented for July 1497 - Schnyder, Malleus Maleficarum, 32 and 62-63 (no. 63), incl. n. 149.

${ }^{61}$ Herzig, Christ, 80.

${ }^{62}$ Herzig, Christ, 76-80. Cf. also above n. 59.

${ }^{63}$ Schnyder, Malleus Maleficarum, 32 and 62 (no. 62).

${ }^{64}$ As to the erroneous dating of the print (the year 1496) Herzig, Christ, 76-77.
} 
for the first time in Venice in $1483 .{ }^{65}$ It was rejected in 1491 by the Church and later put on the Roman index of prohibited books. The condemnation of Rosellis' treatise gave rise in the 1490 s to sharp criticism in Venice. ${ }^{66}$ Institoris was a staunch supporter of papal supremacy and of anticonciliarism. ${ }^{67}$ His Opusculorum, designed to justify the rejection of the above-mentioned treatise by Roselli, was obviously widespread through all of Apennine peninsula $^{68}$ and even influenced Pope Alexander VI. ${ }^{69}$

Alexander VI eventually appointed by a bull, dated 31 January $1499,{ }^{70}$ Institoris jointly with the prior of the monastery in Klosterneuburg Jacob Paperle ${ }^{71}$ as inquisitor

${ }^{65}$ Herzig, Christ, 78-79. Apart from the works cited here also see Roselli e.g. http://www.geschichtsquellen. de/repPers_100968872.html (vidimus 9. 7. 2017); Segl, "Heinrich Institoris," 122.

${ }^{66}$ Herzig, Christ, 78-79.

${ }^{67}$ For the character of Institoris' papalism and anticonciliarism, see Jerouschek, "Heinrich Kramer," 121.

${ }^{68}$ Herzig, Christ, 79-80.

${ }^{69}$ Herzig, Christ, 80. Cf. also below, esp. n. 82.

${ }^{70}$ In Clypeus (Clypeus-print 1501, fol. 4ra) Institoris quotes the date of the papal bull, which is a reprint of his introduction: "anno incarnationis dominice millesimo quandrigentesimo nonagesimo nono, pridie kalendas Februarii pontificatus nostri anno viii”. Quote from the copy of the Bavarian State Library in Munich (Bayerische Staatsbibliothek München), sign. 798943163 Res/2 P.lat. 798. See http://reader.digitale-sammlungen.de/

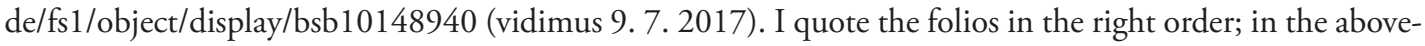
mentioned print from the year 1501 the numbering of the folios is turned upside down, folio 4 following folio 5. See also Schnyder, Malleus Maleficarum, 66, n. 163. - Kubíček, “Jindřich Institoris" (as well n. 1) avoids dating the bull. The correct date of the bull 31 January 1499 referred to in print is quoted by Molnár, "Protivaldenská polemika," 158; Sokol, "Vavřinec Krasonický," 62; Hlobil, "Nejstarší olomoucké knižní dřevořezy," 352, n. 134; Hlaváček, "Inkvizitor," 73; Hlaváček, "Apostolus," 43-44. - The date of the bull 31 January 1500 was suggested in contrast by Hansen, Quellen, 30-31 and 393, in spite of the fact that he quotes the establishing of the date of the bull as the year 1499. Following Hansen, J. Koči dated Institoris' arrival to Moravia as well - Josef Kočí, Čarodějnické procesy. $Z$ dějin inkvizice a čarodějnických procesũ v českých zemich v 16.-18. stoleti \{Witch Trials. From the History of the Inquisition and Witch Trials in the Bohemian Lands in the Sixteenth-Eighteenth Centuries\} (Praha: Horizont 1973), 14. A comprehensive justification of the alleged date of the papal bull as 1500 is provided by Schnyder, Malleus Maleficarum, 65-66, incl. $\mathrm{n}$. 162, who refers to Grotefend's chronological handbook (Hermann Grotefend, Zeitrechnung des deutschen Mittelalters und der Neuzeit, 2 vol., (Hannover: Hahn 1891-1892 (reprint Aalen: Scientia 1984)): “Hier erfolgt die Datierung offenbar nach dem calculus Fiorentinus (Jahreswechsel am 25. März mit Jahreszählung drei Monate $n$ a $c h$ [spaced out by A. S.] unserem Anfang...), während das nächste breve, nur wenige Tage später ausgestellt, unsere Zählung aufweist. Diese Datierung wird durch die Zählung der Pontifikatsjahre gesichert (Alexander VI. Pontifikat begann am 11. 8. 1492)."The only data, which supports the hypothesis of the bull being issued in 1500, is also the eighth year of the pontificate of Alexander VI. It is doubtful, however, that the papal office would use another system of establishing a date in an allegedly only five day younger document, the breve from 5 February 1500 (see below n. 82), also not the allegedly Florentine use of establishing a date. It may be assumed as well that Institoris would pay attention, when preparing the bull for print, to the inaccuracies as to the date and if need be correct them. - Herzig, Christ, 80, avoided quoting the date of the January bull of Alexander VI (she only quotes the erroneous date of the papal brief, 4 February instead of 5 February 1500). For the incorrect date of the bull reports recently Peter Segl, "Deutsche Dominikaner im Kampf gegen Ketzer und "Hexen"”, in Mehr als Schwarz und Weiß: 800 Jahre Dominkanerorden, edited by Elias H. Füllenbach (Regensburg, Verlag Friedrich Pustet 2016), 89-113 and 344-46, esp. 112.

${ }^{71}$ Clypeus-tisk 1501, fol. 3rb; Hlaváček, "Inkvizitor," 73-74; Hlaváček, “Apostolus," 43-44. 
for the Bohemian Lands (in Bohemie Regno ac prouincia Morauie). ${ }^{72}$ The Pope directed in the bull Institoris designed as inquisitor Germanie and papal legate directly to the city of Olomouc and to the diocese of Olomouc to Bishop Stanislav I Thurzo. Institoris set out for the Bohemian Lands at the beginning of February 1499. He arrived in Olomouc soon after in the beginning of March 1499. There is he attested to already on 11 March 1499, when he is referred to in an entry of the Olomouc town Book of Contracts and Last wills as preacher in the parish church of Saint Maurice. ${ }^{73}$ It was an entry concerning a case, when he jointly with (the shortly before appointed) prevost of the Olomouc chapter Augustin Käsenbrot ${ }^{74}$ (her[r] doctor Augustin[us] kazn[n]prott ${ }^{75}$ ), and with the canons and vicars of the above-mentioned chapter sat in the presence of the foremen and journeymen of the furrier's guild in judgement over Catherine, the adulteress wife of Jacob the furrier. ${ }^{76}$ This must have been provost Augustin Käsenbrot, a humanist, Catholic prelate, high royal official and enemy of the Unity of Brethren, ${ }^{77}$ who informed Institoris in a short time about the religious situation in Bohemian Lands, especially about the activities and teaching of the Bohemian Brethren.

Institoris set out back to Italy at the end of the year 1499. His first sojourn in Olomouc, which lasted several months, would have helped him first of all to closer understand the circumstances in his new field of action.

In the summer of 1499 it is already possible to register Institoris in Venice, where he prepared for print his Opusculorum issued there on 27 July. ${ }^{78}$ Not long afterwards, perhaps still in the summer of 1499, he stayed in Augsburg, where he was recorded as having been

\footnotetext{
${ }^{72}$ Clypeus-tisk 1501, fol. 3rb-4ra. Cf. also Schnyder, Malleus Maleficarum, 64-66 (nr. 66) (incl. n. 163).

${ }^{73}$ Zemský archiv Opava \{Land Archives Opava\}, pobočka Státní okresní archiv v Olomouci $\{$ Branch of the State District Archives in Olomouc\}, fond Archiv města Olomouce \{Collection of the Archives of the City of Olomouc\}, book inventory nr. 7 (Liber antiquus contractum et testamentorum 1492-1593), fol. 89r. Institoris is here named as Henricu[s] Doctor, doctor yn [n] den hailigen [n] geschrifft, eyn Bruder prediger orden vnd dieselbige czeit prediger der pfar[r]kirchen[n] S[an]cti Mauricii. It is noteworthy that he is quoted in this entry as preacher at Saint Maurice church and not as an inquisitor. Cf. also Václav Nešpor, "O původu moravského humanisty Dr. Augustina Olomouckého" \{On the Origin of the Humanist Dr. Augustin of Olomouc\}, Český časopis historický 38 (1932): 541-544, esp. 544, n. 2; Hlobil, "Nejstarší olomoucké knižní dřevořezy," 350, n. 99. - He was referred to as doctor "Jindřich" $\{$ Henry\} by the representatives of the Unity of Brethren as well - see below n. 124.

${ }^{74}$ See below, esp. n. 149.

75 See above n. 73.

${ }^{76}$ Zemský archiv Opava \{Land Archives Opava\}, pobočka Státní okresní archiv v Olomouci \{Branch of the State District Archives in Olomouc\}, fond Archiv města Olomouce \{Collection of the Archives of the City of Olomouc\}, book inv. nr. 7, fol. 89r-89v. Cf. also Nešpor, "O původu" 544, note 2.

77 See below, n. 149 .

${ }^{78}$ See above, esp. n. 63 and 64, and below, n. 89.
} 
intoxicated by the city clerk of that place and later renowned diplomat and humanist Konrad Peutinger (1465-1547). ${ }^{79}$ Institoris stayed in Rome the winter of 1499/1500. ${ }^{80}$

Pope Alexander VI issued there for Institoris on 5 February 1500 a brief (breve), in which he more precisely and in detail ${ }^{81}$ defined the tasks connected with his inquisitorial activities in Margravate of Moravia and the Kingdom of Bohemia. These tasks should have consisted first of all in the persecution of the Unity of Brethren ("Bohemian Waldensians") and their heretic treatises. ${ }^{82}$ Pope Alexander VI turned over the same day, on 5 February

${ }^{79}$ Schnyder, Malleus Maleficarum, 64 (nr. 64) dates Institoris' stay in Augsburg after 29 July 1499. - It is questionable whether it can be deduced from only this account that Institoris was a drunk as he was constantly calling out for wine, as stated by G. Jerouschek, "Heinrich Kramer", 118, incl. n. 15.

${ }^{80}$ Herzig, Christ, 80.

${ }^{81}$ Considering the significant details in the papal breve is not any more surprising than the annual interval between the issue of the papal bull and the breve. See also lower n. 82.

${ }^{82}$ Clypeus-print 1501, fol. 5ra-b. - Cf. also Schnyder, Malleus Maleficarum, 67 (nr. 67). In the papal brief is stated "librum seu codicem, quem Copita ipsi nominant" - Clypeus-print 1501, fol. 5ra (cf. also Schnyder, Malleus Maleficarum, 67). Institoris dealt with this book Copita (gen. pl. Copitorum), which was written in Czech, on several places in the tractates Clypeus and Adversus as with a crucial treatise of the "Bohemian Waldensians", without giving the name of its author (see Kubíček, "Jindřich Institoris," 116-118, n. 4). - The author of the book Copitorum was later identified by the German philosopher, scholar and humanist Joachim Camerarius the older (1500-1574) as the Czech religious thinker and initiator of the ideas professed by the Unity of Brethren, closer unknown Petr called Chelčický (around 1390-1460). In Czech postwar research, Chelčický is mainly identified with a member of the lower nobility, the south Bohemian knight Petr Záhorka from Záhorčí (near Chelčice). Camerarius' argument relies nevertheless upon Institoris' identification of the author of the book Copita with a shoemaker - Clypeus-print 1501, fol. 5va (collector libri sutorie artis), which Institoris raises to the legend of an illiterate shoemaker master - Kubíček, "Jindřich Institoris," 116-117, n. 4 (auctor illius collecturae fuit sutoriae artis magister, habens flium scribens ex ore patris). See Joachim Camerarius, Historica narratio de fratrum orthodoxorum ecclesiis in Bohemia, Moravia et Polonia (Heidelberg: Voegelin 1605), 81: "(Rokyzana) ita eos dimisit, ut juberet legere diligenter treatisea Petri Chelzicii. Hic scripsit multa sermone bohemico, et sunt quaedam conversa in Latinum sermonem superioribus annis, una cum Hussi treatiseis edita. Hominem perhibent fuisse probum et pium et valde ingeniosum, quamvis literarum eruditarum imperitum, et in officina educatum. Fuit enim sutor, unde ab adversariis Doctor Kopytarum appellabatur. Nam modulus calceorum hoc nomine bohemice vocatur Kopyto, quod Graecis est calopodium. Capitibus etiam distinguendo treatiseum suum, quae essent XL. et singula numerando Kopyta illa nominavit. Atque hunc inprimis Papisticae factionis treatiseores contumeliis exagitarunt et laceraverunt conviciis, conditione hominis humili occasionem dante variis dictis, quae in illum abs malevolis dicerentur." - The oldest known identification of Chelčický with a Prague artisan goes back to Jan Vodňanský (Aequensius) (around 1460-after 1534), (at the time already) a Franciscan friar from Bechyně. Vodňanský in his tractate Proti bludným a potupeným artikulóm pikhartským \{Against the False and Disgraced Articles of the Picards\} of the year 1502, printed for the first time probably in Plzeň (germ. Pilsen) already in 1505 and without doubt for the second time in 1510, stated that a shoemaker from Prague Petr Kelčanský had written books called by the Bohemian Brethren (picards) "Kopytorum" - see Josef Truhlár, "O životě a spisech známých i domnělých bosáka Jana Vodňanského" \{On the Life and Known and Alleged Writings of the Barefoot Friar Jan Vodňanský\}, Časopis Musea Království českého 58 (1884): 524-547, esp. 535. Truhlář, "O životě a spisech" refuted the opinion of J. Jireček (Jireček, Rukovět', vol. I, 298), that the Prague Franciscan friar Wolfgang should be considered the author of the aforementioned tractate. - This explanation of the origin of the designation book of Copita was taken over by the majority of researchers (Kubíček, "Jindřich Institoris," 116-118, note 4; Hansen, Quellen, 393-394; Sokol, "Vavřinec Krasonický," 63 and 97, n. 72; Molnár, "Protivaldenská polemika," 158). For a much more sceptical attitude towards this 
1500 , a request for support in the fight against the Bohemian heretics to the land governor (germ. Landeshauptmann) of Margravate of Moravia (capitaneus terrae Moraviae) Jan Meziříčský of Lomnice. ${ }^{83}$

It may be considered almost certain that the installment of Institoris as inquisitor for the Bohemian Lands and his arrival in Moravia were - be it directly or indirectly - initiated by (the not long ago confirmed) Bishop of Olomouc Stanislav I Thurzo. ${ }^{84}$ Thurzo is quoted in a bull from 31 January $1499,{ }^{85}$ and in the papal breve as well. ${ }^{86}$ Institoris was, by power of the brief, given the opportunity to make a choice of two or three persons to help him in fulfilling his duties, who would be able to preach in the Czech language. ${ }^{87}$ He would have the right to confer on them the title of master (magister) of theology ${ }^{88}$ The breve from 5 of February demonstrates that Alexander VI was impressed by Institoris' critique of Rosellis' treatise which he expressly mentions here (tractatus et sermones contra quocuscumque perfidorum errores a te vel ab aliis per sanam doctrinam collectos hoc anno eciam contra peruersa dogmata Anthonii Rosellis dudum per sedem apostolicam condempnata nobis presentatos) and which he obviously had fresh in his memory at that time. ${ }^{89} \mathrm{On}$

identification with Chelčický, see Schnyder, Malleus Maleficarum, 67, n. 165. - Within the framework of the works by Petr Chelčický is the book Copita being identified with his treatise Řeč o šelmě a obrazu jejiem \{Speech about the Beast of Prey and her Image\} (Jireček, Rukovět, vol. I, 291). This text is handed down in one of the first manutreatise volumes of writings by Chelčický from the middle of the fifteenth century, which is currently deposited in Olomouc (Státní vědecká knihovna v Olomouci/State Scientific Library in Olomouc, sign. M I 164). A critical edition of this volume was recently prepared by J. Boubín - Petr Chelčický, Spisy z Olomouckého sborníku \{Petr Chelčický. Writings from the Olomouc Volume\}, ed. by Jaroslav Boubín (Praha: Hixstorický ústav 2016), esp. 277-302. - Kubíček, "Jindřich Institoris," 117-118, n. 4, draws attention to the contradiction consisting in the fact that Institoris writes about the book of Copita containing 40 copita/kopyta (= chapters), while the aforementioned treatise by Chelčický consists in the Olomouc manutreatise of only 17 chapters. In spite of this Kubíček refuted the opinion that Institoris' words "about the book Copitorum and its author have no connection with the person of Chelčický or with another writer, but are only placed there as a casual way of designating the literature of the Bohemian brethren in general". This is because Institoris did not only carry out a polemic with the treatise Řeč o šelmě a obrazu jejiem, but with other texts contained in the above-mentioned Olomouc volume. The designation kopyto, which in this connection means in Czech a shoemaker's tool, is clearly - as Kubíček argues as well (Kubíček, "Jindřich Institoris," 118, n. 4) - a corruption of the Latin designation of a chapter (caput, capitulum). The described corruption may have originated in the process of copying Chelčickýs works as a coruptela and may have become the custom by the end of the fifteenth century for a certain time especially among the adversaries of the Unity of Brethren, providing them with a welcome occasion to defame the main initiator of the new church as an illiterate Prague shoemaker, who had dictated to his son a book attacking the Catholic church. ${ }^{83}$ Josef Macek, Vira a zbožnost jagellonského věku \{Faith and Religiosity of the Jagiellonian Age\} (Praha: Argo 2001), 250-251. Cf. also Hlaváček, "Apostolus," 44.

${ }^{84}$ See below in more detail.

${ }^{85}$ Clypeus-print 1501, fol. 3va.

${ }^{86}$ Ibidem, fol. 4ra.

${ }^{87}$ Ibidem, fol. 4rb.

${ }^{88}$ Ibidem. Cf. also Hlaváček, "Inkvizitor," 74.

${ }^{89}$ Clypeus-print 1501, fol. 4rb. Vgl. also Schnyder, Malleus Maleficarum, 67; Herzig, Christ, 80. - Schnyder, Malleus Maleficarum, 67, n. 167, states as the year of the issue of the treatise Opusculorum in errores 'Monarchie' 1499 as well (27. VII.). Cf. also above n. 64. 
11 February 1500 Institoris received in Rome a letter of recommendation from the superiors of his order as well, addressed to the prior of the Dominican convent of Saint Michael in Olomouc (priori conuentus Ollomucensis), with a charge to arrange for Institoris a room in the convent, where he might carry out his duties as inquisitor. It had to be the room where once sat as judges domini barones Ladislaus et Carolus..$^{90}$ The same day the superiors ordered the vicar Joannes de Beccha to pay out to Institoris for his inquisitorial mission 100 florins (centum florenos de Camera pro officio inquisitionibus). ${ }^{91}$

Institoris arrived in Olomouc for the second time sometime during the spring ${ }^{92}$ of the year $1500 .{ }^{93}$ His two journeys to Olomouc are also proven by the dating of the papal bull from 31 January 1499, the Olomouc entry from 11 March 1499 and his verifiable stay in Rome in the winter of 1499/1500, and also by the circumstance that Institoris made already in the polemics Opusculorum, published in Venice in the summer 1499, not only mention of the book Copita, but wrote as well about Litomyšl (germ. Leitomischl) and Přrov (germ. Prerau) as centres of the Unity of Brethren (in Lythomischil aut Przerow, ubi Copitorum a auctoribus leguntur), which assumed a detailed knowledge of the Bohemian, let us say Moravian, religious circumstances. ${ }^{94}$

The contents of the papal breve from 5 February 1500 testify to the fact that it was not issued after five days, but more than a year after the delivery of the installment bull. Its formulations show in several places a rather detailed knowledge of the religious circumstances in the Bohemian Lands and the situation in the land in general. Certain passages

${ }_{90}$ Schnyder, Malleus Maleficarum, 68 (nr. 68). See also Hansen, Quellen, 379 (nr. 59). - Ladislaus was a leading Moravian humanist and bibliophile Ladislav Černohorský of Boskovice (around 1455-1520), who had held since 1496 the office of the highest chamberlain of the Margravate of Moravia. The lord named Carolus could have been Karel the younger Vlašimský of Úsov (died 1500). I expresss my deep gratitude for this identification to my colleague PhDr. Tomáš Baletka, PhD.

${ }^{91}$ Schnyder, Malleus Maleficarum, 68 (nr. 69). See also J. Hansen, Quellen, 379-380 (nr. 60).

${ }^{92}$ Herzig, Christ, 82, states that Institoris entered in March 1500 through an intermediary of his order brethren in Lombardy in contact with a member of the Terciary Dominican order Lucy Brocadelli from Narni. Schnyder, Malleus Maleficarum, 64 (nr. 65) in contrast estimates with reference to Clypeus, that Insitoris possibly met Lucy Brocadelli already at the beginning of the year 1500 in Ferrara.

${ }_{93}$ The time of Institoris' second arrival to Olomouc lies in a time space between the issue of the breve of Alexander VI on 5 February 1500 and his dispute in Olomouc with the representatives of the Unity of Brethern (see below), which the majority of the existing literature rightly places at the commencement of the second half of the year 1500 (Sokol, "Vavřinec Krasonický," 64). His first sojourn in Olomouc would have undoubtedly been in the spring of 1499 and with a demonstrable contact with Käsenbrot at this time, had Institoris been limited to only two or three months, also a very short time, in his endeavour to learn in person about the circumstances of the Czech and Moravian ecclesiastical circumstances and have a closer look at the doctrine of the Unity of Brethren. - Herzig, Christ, 148-149, states incorrectly (and within the context of her work quite nonsensically), that Institoris did not come to Olomouc until 1501.

${ }^{4}$ To this points Molnár, "Protivaldenská polemika," 169, n. 42. - Hlaváček, "Inkvizitor," 72, expresses clearly the opinion that Institoris "had many-sided information about the Czech ecclesiastical-political situation". (Cf. too Hlaváček, "Apostolus," 42-43.) Kubíček points to, in contrast, his serious ignorance of Czech and Moravian ecclesiastical history, recognizable when studying Clypeus - A. Kubíček, "Jindřich Institoris," 225, n. 5. See also in more detail below. 
of the breve may be even considered a direct reaction to the foregoing exploration of the circumstances prevailing in both Bohemia and Moravia. The bull repeatedly makes mention of the prouincia Moranie, taken obviously for a particular part of the Kingdom of Bohemia (Bohemie Regnum), ${ }^{95}$ only to be correctly stated as the Margravate of Moravia (marchionatum Moranie) in the breve. ${ }^{96}$ The breve also takes into consideration the circumstance that in both countries the majority of the population spoke Czech. ${ }^{97}$ The bull invested Institoris with the general authority to persecute heretics, witches, sorcerers and their supporters in the Bohemian Lands. ${ }^{98}$ Alexander VI mentions in the brief his predecessor Innocenz VIII, editor of the "witches bull" Summis desiderantes affectibus (of 5 December 1484), but there is no mention in the breve of witches or magic art. ${ }^{99}$ In contrast, the brief deals with the book Copita and its annihilation. ${ }^{100}$

One might ask if Institoris stopped during his two journeys to Olomouc (and one from Olomouc) in the metropolis of the Kingdom of Bohemia and of the Lands of the Crown of Bohemia, Prague. ${ }^{101}$ It cannot be excluded, but I take it as highly improbable. I am of the opinion that Institoris travelled from Italy to Olomouc by the shortest way, e.g. through Venice and Vienna, and avoided each time the diversion to Prague. ${ }^{102}$ Even if he had visited Prague, he would not have been able, as he maintains in Clypeus, ${ }^{103}$ to participate in the dispute, which had taken place in the presence of the King of Bohemia and Hungary Vladislaus Jagiello (1456-1516; King of Bohemia 1471-1516, King of Hungary since 1490). King Vladislaus did not stay at all in either 1499 or 1500 in Prague and in

${ }^{5}$ Clypeus-print 1501, fol. 3rb-3vb. - It is to ask what territorial limits of authority were defined by Alexander VI to Institoris by virtue of the formulation "per vicinas regni Bohemie sed et per omnes Germanie nacionis partes" (see Schnyder, Malleus Maleficarum, 65). Contrary to Hlaváček, "Inkvizitor," 73-74 my opinion is that the formulation does not apply to the whole of Germany, but that it concerns only the other Lands of the Crown of Bohemia (especially Silesia) inhabited mainly by German speaking ethnic groups and also the ethnic German border regions of the Bohemian Lands. Also justifiable is the hypothesis that the formulation could testify to the limited knowledge of Pope Alexander VI as to the political and ethical conditions in Central Europe.

${ }^{96}$ Clypeus-print 1501, fol. 4ra.

${ }^{97}$ Clypeus-print 1501, fol. 4rb.

${ }_{98}$ Clypeus-print 1501, fol. 3vb-4ra: “... hereticorum, maleficorum et magycarum arcium sectatores”. Cf. also Schnyder, Malleus Maleficarum, 65.

${ }_{99}$ Clypeus-print 1501, fol. 4rb. Cf. also Schnyder, Malleus Maleficarum, 67.

${ }^{100}$ Clypeus-print 1501, fol. 4ra-4rb.

${ }^{101}$ Hlaváček, "Inkvizitor," 74, incl. n. 25, assuming that Institoris arrived in the Czech Lands not before 1500, states with reference to Opusculorum, that "Institoris came still in 1500 from Salzburg to Prague". (Cf. also Hlaváček, "Apostolus," 44.) Institoris' activities in Salzburg are only documented, however, for the years 1493-1495 - Schnyder, Malleus Maleficarum, 31 and 60 (nr. 55 and 56), 60-61 (nr. 57) and 61 (nr. 58).

102 The journey from Rome to Olomouc on the aforementioned track consists of 1350 kilometres. By way of Prague the journey would be prolonged by more than 250 kilometres - Institoris' documented sojourn in Augsburg in 1499 (see n. 79) followed obviously after his stay in Venice.

${ }^{103}$ King Vladislaus Jagiello stayed in Prague after his departure from Hungary in 1490 for the first time (and the last time before 1500) on the occasion of the Whitsun assembly held in May 1497 and stayed there only until November of the same year - see for instance: Václav Vladivoj Tomek, Dějepis mèsta Prahy \{History of the City of Prague\}, vol. IX, 1. ed. (Praha: W komissí u Františka Řiwnáče 1893). 
the Bohemian Lands and resided for a long time in Hungary, mainly in Buda. ${ }^{104}$ There remains only a possibility to assert as a hypothesis that Institoris visited the metropolis of Bohemia sometime between 1471-1490 or in 1497, when King Vladislaus dwelt mainly in the capital city. ${ }^{105} \mathrm{~A}$ more probable explanation is that the passage about the dispute in the presence of King Vladislaus in Clypeus is nothing else but a pure fabrication of Institoris. ${ }^{106}$ Stanislav I Thurzo (1471/72-1540), who most probably initiated Insitoris' arrival in Olomouc, had been elected bishop of Olomouc in 1496 by the local chapter and at the end of January 1497 confirmed by Pope Alexander VI in his office. ${ }^{107}$ Stanislav I Thurzo (born in Cracow) was the third son of the successful Hungarian mines and works contractor Johann III Thurzo (1437-1508). ${ }^{108}$ His older brother, an important humanist Johann IV Thurzo (1466-1520), became Bishop in Silesian Vratislav in 1506. ${ }^{109}$

The long episcopacy (1497-1540) of the humanist oriented Stanislav I Thurzo saw the issue of new diocesan statutes (1498), witnessed the consolidation of the episcopal property;

${ }^{104}$ King Vladislaus did not fulfill his promise given to the Bohemian Estates in November 1499 during negotiations in Pressburg (today Bratislava), that he would come to Bohemia in the spring of 1500, and he remained in Buda - see e. g. Vladislavské zrízení zemské a navazujíci prameny (Svatováclavská smlouva a Zř́zení o ručnicích). Edice \{The Vladislaus Constitution and Related Sources (The Saint Wenceslas Agreement and the Ordinance Concerning the Rifles). Edition\}, edited by Petr Kreuz and Ivan Martinovský (Praha and Dolní Břežany: Scriptorium 2007) 47. King Vladislaus returned from Hungary to Prague for the second time not before the beginning of the year 1502 to preside over the Lent assembly inaugurated on 21 February 1502 - see e. g. Vladislavské zrízeni zemské, 53.

${ }^{105}$ Clypeus-print, fol. 23ra: “... contra quem errorem et alibi scripsimus quinimo et per publicas disputaciones in castro Pragensi in presencia Regie maiestatis Vladislai conclusum fuit” (see also Clypeus-print 1502, fol. $21 \mathrm{rb}$ ). ${ }^{106}$ On Institoris being a great and shameless liar - sometimes giving incorrect examples - Jerouschek, "Heinrich Kramer," 122. - It is embarrassing that even the authors, whose valuation of Institoris' personality is wholly negative, often uncritically believe what he wrote. In the case of the alleged Prague dispute should be named esp. Hlaváček, "Inkvizitor," 74, incl. n. 26, who developed the cited (see above n. 105) assertion of Institoris into an audacious hypothesis, when he writes that Institoris was "received by King Vladislaus Jagiello in Prague. He took part in a public disputation about the Utraquist communion at the Prague castle in the presence of the King (under both species/sub utraque specie). He carried on a controversy with the rektor of Charles University Václav of Pacov and the administrator of the Prague Utraquist consistory Pavel of Žatec." In this case is also thought to be merely the result of a wish: If Institoris were to carry on a dispute at the Prague castle before King Vladislaus his partners in the dispute would have been the best Utraquist theologians, which were available at that time in Prague... Cf. too Hlaváček, "Apostolus," 44: "Heinrich Institoris kam 1500 von Salzburg [sic - P. K] ... nach Prag. Er wurde von König Wladislaw Jagiello persönlich empfangen. Dieser war auch zugegen, als er auf der Prager Burg an einer öffentlichen Disputation über die Kommunion unter beiderlei Gestalt teilnahm. Wahrscheinlich [sic - P. K] polemisierte Institoris bei jener Gelegenheit mit dem Universitätsrektor Wenzel von Patzau und dem Administrator des Utraquistischen Konsistoriums, Paul von Saaz."

${ }^{107}$ Kubíček, "Jindřich Institoris" 21-22, writes, that Alexander VI sent Institoris to the Bohemian Lands "certainly at the instigation of Bishop Stanislav".

${ }_{108}$ Der lateinische Briefwechsel des Olmützer Bischofs Stanislaus Thurzó. Eine ostmitteleuropaische Humanistenkorrespondenz der ersten Hälfte des 16. Jahrhunderts, edited by Martin Rothkegel (Hamburg: Lit-Verlag 2007) 14-15.

${ }^{109}$ Josef Joachim Menzel, "Johannes V. Thurzo," in Neue Deutsche Biographie, vol. 10 (Berlin: Duncker \& Humblot 1974), 482-483. 
Thurzo distinguished himself with extensive and large-scale building activities. ${ }^{110}$ Before his accession, the bishopric had been since 1482 in a state of sedisvacation. ${ }^{111}$ Thurzo had available numerous influential contacts in home from the time of his negotiations about the termination of the sedisvacation of the bishopric of Olomouc. It seems that he was unable to make use of their help in solving the complex religious, if you like confessional, situation in his diocese by sending a papal inquisitor. Alexander VI turned nonetheless in his bull and his breve to Thurzo (whom he obviously knew in person ${ }^{112}$ ) as the highest dignitary of the Catholic church not only in Moravia, but in the Bohemian Lands on the whole, and at a time, when the archbishopric of Prague had been in the state of sedisvacation for a long decades. In the spring of 1499 Institoris was obviously warmly welcomed by the young Bishop in Olomouc. ${ }^{113}$

As late as his second arrival in Moravia, the Dominican friary of St. Michael in Olomouc became, in accordance with the wording of the papal breve, ${ }^{114}$ the official seat of Institoris as an inquisitor. There is a possibility that already during his first stay in the spring of 1499 Institoris may have sojourned in the town of Kroměríz (in German Kremsier), which had been since the second half of the thirteenth century the centre of the administration of the diocese of Olomouc. ${ }^{115}$ At the time of his arrival in Moravia, Stanislav I Thurzo had already bought Kroměríž with its chateau and adjacent dominion from pawn and initiated at the turn of the sixteenth century large-scale rebuilding of the fortress of Kromeréíz into a two-wing Gothic-Renaissance castle. ${ }^{116}$

As already hinted, ${ }^{117}$ Institoris oriented himself in a relative very short time in the Bohemian and Moravian ecclesiastical and denominational conditions and made an acquaintence with the teaching of the Unity of Brethren. Up until his arrival in Moravia, he

${ }^{110}$ Concerning the person and activities of Bishop Stanislav I Thurzo and the diocese of Olomouc under his episcopacy, see the latest and most fully Tomáš Baletka, "Dvůr olomouckého biskupa Stanislava Thurza (1497-1540), jeho kancelár a správa biskupských statkư" \{The Court of the Bishop of Olomouc Stanislav Thurzo (1497-1540), his Office and the Administration of the Episcopal Estates\}, Sbornik archivnich praci 54, no. 1 (2004): 3-236. See also Der lateinische Briefwechsel (as n. 108).

${ }^{111}$ Held the office of the administrator of the bishopric from 1493 onwards and the Pope's related archbishop of Monreale cardinal Juan (John) XV. de Borgia (1446-1503, archbishop 1483-1503, cardinal since 1492), who was also bishop in Ferrara and Melfi. Stanislav I Thurzo succeeded in the years 1495-1496 after difficult negotiations in Rome, where he was sent by the chapter of Olomouc as its canon to receive from the Pope the renewed recognition of the right of the chapter to elect freely the bishop and to induce Juan de Borgia to renounce the payment for the post of an administrator. The latest provided by Antonín Kalous, "Spor o biskupství olomoucké v letech 1482-1497" \{Controversy about the Bishopric of Olomouc in the Years 1482-1497\}, Český časopis historický 105 (2007): 1-39. Cf. also Baletka, “Dvưr," 7-9.

112 Cf. above n. 111.

${ }^{113}$ Herzig, Christ, 114, deduces it from the fact that Institoris dedicated the later Clypeus to bishop Thurzo. The dedication see Clypeus-print 1501, fol. 4v-5r. The critical edition is the work Der lateinische Briefwechsel, 91-96.

${ }^{114}$ See above n. 82.

115 Baletka, "Dvůr," 37.

${ }^{116}$ Baletka, "Dvůr," 37-38; Der lateinische Briefwechsel, 31, incl. n. 66.

117 See above n. 93. 
had mainly known about the doctrine and opinions of the Brethren from their opponents. He believed the slander and absolute concoctions, e.g. about piercing the host ${ }^{118}$ or orgies perpetrated during ceremonies. ${ }^{119}$ He early showed an interest in getting to know the Bohemian brethren in person as well and contending with their representative in discussions. ${ }^{120} \mathrm{He}$ did not therefore invite to Kromerřiž the learned representatives of the Unity of Brethren to debates, but to friendly talks at his expense. No one accepted his invitation, despite the fact that the Bohemian brethren appeared in the town. ${ }^{121}$ At last it came to an appointment obviously through the intermediary of unknown persons from among the Catholic nobility. ${ }^{122}$ The appointment itself was nonetheless mediated by a certain unnamed member of the Lord's Estate at the request of Institoris, who pretended that he wanted to join the Unity of Brethren. ${ }^{123}$ After having used this trickery, ${ }^{124}$ he succeeded in persuad-

${ }^{118}$ According to the later reminiscence of Vavřinec Krasonický in his treatise Vyznání o těle a krvi Páně \{Confession about the Body and Blood of God\} Institoris did not hesitate to use the assertion about the piercing and bleeding of the host even during the dispute in Olomouc - see Justová, Tưma Př́loučský, 75: "A tu nám doktor Jindrich enquisitor heretice pravitatis v Holomúci pod prísahú jistil a pravil na pikharty." \{And there the doctor Henry, enquisitor heretice pravitatis in Olomouc, assured and accused them under oath as picards.\} For the dispute see fully lower.

119 Sokol, "Vavřinec Krasonický," 63 and 97, n. 74.

120 Sokol, "Vavřinec Krasonický," 63.

${ }^{121}$ Sokol, "Vavřinec Krasonický," 63.

${ }^{122}$ Molnár, "Protivaldenská polemika," 159, resigned unfortunately at the attempt "to investigate, which Catholic noblemen in Bohemia and Moravia, especially from the circle around Bishop Stanislav Thurzo, established relations and collaboration with Institoris".

123 Sokol, "Vavřinec Krasonický," 63.

${ }^{124}$ This trickery was later described in an apologetic tractate, named in literature as either Odpovéd" na listy doktora Augustina \{Answer to the Epistles of Doctor Augustin\} (V. Sokol) or Známo bud' v̌sem \{Let it be Known to All\} (A. Molnár). The author is considered the theologian and bishop of the Unity of Brethren Lukás Pražský \{Lucas of Prague\} (see also lower n. 152). This tractate is a polemic with the Epistles of Augustin Käsenbrot, who was a titular prevost of the Olomouc chapter since 1498 (Baletka, "Dvưr," 8; see below more fully n. 149). The author of the polemic placed Institoris on the same level as Käsenbrot. At the same time it is a unique testimony concerning Institoris' behaviour and manners coming from his Czech adversaries (cit. according Molnár, "Protivaldenská polemika," 172, n. 64, cf. as well Sokol, "Vavřinec Krasonický," 97, n. 76): “... to činí jako i jeho tovařiš Jindřich doktor, vyhledavač kacierunov, poslaný s listem od papeže do Čech a do Moravy, kterýżto žádal skrze pána jednoho i skrze jiné, aby mohl mluviti s námi, jakoby chtěl našim bratrem býti. A když některí s ním mluvili v Olomúci v konventu, tu se s nimi objímal a vuodci děkoval, že tak dobré lidi privedl, bratrími je nejmilejšimi nazývaje, i nápojem ctil a prátelsky se rozžehnal. Hle, zdálo se čisto a svato, ano pak všecko ve lsti a neupríemnosti bylo. Neb ty některé zejména vepsal v knihy, arcikacieře a bludaře svědče býti i Čechy. A těch knih některé sto vytisknúti kázal.” \{...this makes [Augustin Käsenbrot] and his colleague Henry the doctor, who is looking for heretics, sent with a papal epistle to Bohemia and Moravia, who asked through the intermediary of one lord and through others, to talk with us, as if he wanted to become our brother. And some of us talked with him in Olomouc in the convent, he embraced us and expressed his thanks to the leader, that he brought such good people, calling them most beloved brothers, and honoured them with beverage and told them a friendly good-by. Lo, it seemed to be clean and holy, what afterwards became artifice and insincerity. Because he especially entered some of them into books, and bore witness, that the Czechs are arch-heretics and misbelievers as well. And he had some hundreds of those books printed.\} - Tractate Odpovéd'na listy doktora Augustina, let us say Známo bud'všem arose most probably in December 
ing the representatives of the Unity of Brethren to call on him at the Dominican friary in Olomouc, ${ }^{125}$ where they were ceremonially cordially welcomed by him. ${ }^{126}$

Leading theologians and defenders of the Unity of Brethren Tưma (Tomás/Thomas) Preloućský (cca 1435-1518), the joint founder and bishop of the Unity, operating in nearby Přerov, and Vavrinec Krasonický, called Lorek (1455/60-1532), the then administrator of the Brethren congregation in Litomyšl came to Olomouc to debate with Institoris. ${ }^{127}$ Tůma was predestined for this task by his rank in the Unity of Brethren in Moravia, while Krasonický was led to Olomouc by a consideration of his own, that from the common discussion could arise something good. ${ }^{128}$ The debate in the Olomouc Dominican friary took place sometime at the beginning of the second half of the year $1500 .{ }^{129} \mathrm{~A}$ dominant person in the dispute which took place in Olomouc was obviously on the side of the Unity of Brethren Krasonický: ${ }^{130}$ Institoris mentions only him in Clypeus. ${ }^{131}$

1507, its printing was concluded on 6 of January 1508 in Litomyšl - Molnár, "Protivaldenská polemika," $160-161$ and 172 , n. 64.

125 Sokol, "Vavřinec Krasonický," 63-64.

${ }^{126}$ Sokol, "Vavřinec Krasonický," 64. See also above n. 124.

127 Sokol, "Vavřinec Krasonický," 63-64.

128 Sokol, "Vavřinec Krasonický," 64 and 98, n. 78.

${ }^{129}$ Sokol, "Vavřinec Krasonický," 64. Cf. also Justová, Tưma Přeloučský, 73-74. See also above n. 93. Hlaváček, "Apostolus," 45, incorrectly stated that the disputation took place in the winter of 1500.

${ }^{130}$ Krasonický could have argued on similar lines as he did in the dispute held in July 1497 in Litomyšl with the Bishop of Djakovo (Bosnia), Black friar Gabriel Polnar (Polver) (ep. 1494-1502). The aforementioned Bishop belonged to the retinue of King Vladislaus, who stopped over at that time in Litomyšl at the Lord Bohuše Kostka of Postupice, protector of the Unity of Brethen - see Českobratrská výchova pred Komenským \{The Education Provided by Bohemian Brethren before Comenius\}, edited by Amedeo Molnár (Praha: Státní pedagogické nakladatelství 1956), 55-58; Sokol, "Vavřinec Krasonický," 61-62 and 96.

${ }^{131}$ Sokol, "Vavřinec Krasonický," 97-98, n. 77. - Neither Krasonický nor Tůma give the name of their colleague in their later references to the dispute taking place in Olomouc. Tůma's participation in the dispute is not documented, but is mentioned in his epistle to Czech Lord Albrecht of Sternberg from 1502, in which the writer mentions, that Institoris (indicated as "pan doctor, starý vyhledavač kacírü" \{Doctor, who has been Hunting for Heretics for a Long Time\}) narrated in Olomouc about cases of wonderful holiness in Italian nunneries - see Tưmy Přeloučského spis o piovodu jednoty bratrské a o chudých lidech \{Tůma Přeloučskýs Treatise on the Origin of the Unity of Brethren and the Poor People\}, edited by Vojtěch Sokol (Praha: Melantrich 1947), 67-68. Cf. Sokol, "Vavřinec Krasonický," 97-98, n. 77; Justová, Ti̛ma Přeloučský, 75. - For the translation into German of Tůma's epistle see Schnyder, Malleus Maleficarum, 72-73 (nr. 77). Cf. as well Herzig, Christ, 99-100, n. 67. - For an eventual psychoanalytical analysis of Institoris' personality, attempted some time ago by G. Jerouschek (see above n. 25), it is possible to quote one seemingly marginal even curious circumstance. Krasonický may have him interested not only because of his dominance on the side of the Unity of Brethren, good knowledge of Latin and thought ought and effective theological argumentation, but also by the fact, that he was castrated. In the last of the epistles to Jan Černý, written in 1503 (see below n. 152), Augustin Käsenbrot wrote that Krasonický was castrated (eviratus ille atque emasculatus eunuchus), would not be received in Rome, because he was neither man nor woman (neque masculus sit neque femina) - see Sokol, "Vavřinec Krasonický," 97-98, n. 77. Krasonický never refuted this rebuke. On the contrary, he approved of castration as a deed having its source in the treatiseures, to which had acceded many married and unmarried men "in order not to fall into any sin" - Sokol, "Vavřinec Krasonický," 101, n. 97. There 
As concerns the course of the dispute which took place in Olomouc, we can register in the sources of the Brethren origin only several scattered and for the most part incomplete references. ${ }^{132}$ The main, detailed, but nonetheless biased source about the dispute are the tractates Clypeus and Adversus. In spite of this tendentiousness we may rely on Clypeus and Adversus in order to understand the themes and questions which became the object of the dispute. ${ }^{133}$ It was somewhat more difficult in the case of the concrete argumentation or even its own course. ${ }^{134}$ Based on three answers of the Unity of Brethren to Clypeus, about which the Bishop of the Unity of Brethren Lukáš Pražský \{Lucas of Prague\} ${ }^{135}$ wrote in May 1505 in his written reaction to the tractate of the Black friar Jan Vodňanský, ${ }^{136}$ only a Latin polemic by Krasonický has been preserved in extracts cited in a polemic treatise from the Bavarian theologian, geographer and humanist Jacob Ziegler (about 1470-1549) Contra haeresim Valdensium libri quinque (print Leipzig 1515). ${ }^{137}$

According to the view of Czech evangelical oriented historiography, Institoris was during the dispute in Olomouc disagreeably surprised, and even sustained a shock by the experience of the theological knowledge and high level of the representatives of the Unity of the Brethren. ${ }^{138}$ The dispute was, however, a strong impulse to write the tractates Clypeus and Adversus, of which mainly the first named was rather extensive. ${ }^{139}$

Both tractates originated in all probability during the autumn of 1500 and were delivered to press obviously not earlier than the beginning of the year $1501 .{ }^{140}$ Both tractates were

is also free room for speculations that Institoris, in his fanatic urge for (sexual) purity, subconciously felt a certain affinity with Krasonický (cf. Jerouschek, "Heinrich Kramer," 134-135).

132 Schnyder, Malleus Maleficarum, 72-73 (nr. 76-79). See also above notes 118, 124 and 131.

${ }^{133}$ Kubíček, "Jindřich Institoris," 115-121, 222-226, 320-325, 372-378, 491-500 and 521-525. According to Kubíček, the two tractates are an important source for the study of the Unity of Brethen (Kubíček, "Jindřich Institoris," 222). - In the 1980s the German medievalist P. Segl drew attention to this fact, Institoris acknowledged in Clypeus (Clypeus-print 1501, fol. 81ra) being an independent author of the Hammer of Witches, because he writes here, that he has summarized his opinions on witches in tractatu mallei maleficarum - Segl, "Heinrich Institoris," 117, incl. n. 72. Cf. also Segl, "Deutsche Dominikaner," 112; Kubíček, "Jindřich Institoris," 373-374, n. 3.

${ }^{134}$ For an attempt to comprehend concisely the progress of the dispute and the argumentation of the participants, see Sokol, "Vavřinec Krasonický," 64-65.

${ }^{135}$ Schnyder, Malleus Maleficarum, 72 (nr. 79). Cf. also below n. 152.

136 See above n. 83.

${ }^{137}$ Sokol, "Vavřinec Krasonický," 98, n. 78, 99-101, n. 86, and 108.

138 The most exact formulation is that by Hlaváček, "Inkvizitor," 76, according to whom Institoris "was a little in a state of shock, having to dispute with uneducated simpletons and was forced to ward off in a Latin dispute very convincing arguments founded on the Bible and old Christian tradition." Cf. also Hlaváček, "Apostolus," 45: "Henrich Institoris war gleichwohl in höchstem Maße schockiert. Er hatte in Mähren Gespräche mit ungebildeten Einfaltspinseln erwartet, musste aber in einer lateinischen Disputation genaue Belegstellen aus der Bibel und der altchristlichen Tradition parieren."

${ }^{139}$ In the first edition (cf. above n. 4) Clypeus counted almost 180 and Adversus more than 60 printed pages. ${ }^{140}$ M. Rothkegel (Der lateinische Briefwechsel, 91) dates Institoris' dedication to Bishop Thurzo to as early as 30 of September 1500 . He does not try to justify this date. The dedication itself is not dated. Institoris affirms in his dedication, however, that his opus had been already approved by the Bishop. It can be thus deduced, that at the time when the dedication was written it was in substance finished. Even if Institoris 
printed in Olomouc with the date of issue 20 April 1501 by the itinerant German printer, bookbinder and gifted wood engraver Konrad Baumgarten (born before 1480 in Rothenburg am Neckar, $\dagger$ after 1509). He learned the printer's trade in Magdeburg and Lübeck. He began his career as a book printer at the turn of the year 1499 in Gdańsk (germ. Danzig), where he had before that operated a bookbinder's workshop. ${ }^{141}$ He had moved to Olomouc at the instigation of Bishop Stanislav I Thurzo, who had expected that he would publish Counter-Reformation titles. Baumgarten is documented in Olomouc from autumn 1500 to March $1502 .{ }^{142} \mathrm{He}$ arranged during that time at least 12 Latin prints, including one incunabula and several one-sheets, and one German title as well. ${ }^{143}$ In the years 1503-1506 Baumgarten operated in Vratislav and in 1506-1509 is attested to in Frankfurt/Oder, where he became typographer of the newly opened university. ${ }^{144} \mathrm{He}$ introduced a great number of new elements into book printing in the Bohemian Lands. Paradoxically, he had available a greater supply of types than all the Bohemian and Moravian stationary printing houses and became by degrees a dexterous wood engraver as well. ${ }^{145}$

Baumgarten's production in Olomouc was focused on customers in Silesia, mainly in Vratislav, but Moravia was not neglected either. Despite the fact that the leading German book printer and first publisher of the Hammer of the Witches Peter Drach from Speyer took up since the 1480s - through the intermediary of his commercial agent Johann Schmidhofer with warehouses in Jihlava (germ. Iglau), Brno (germ. Brünn) and Olomouc - an important place on the Moravian book market, and although his selection surpassed many times the capacities of the local printing houses competing with him, ${ }^{146}$ a Moravian provenance can be documented in the case of many extant products of Baumgarten's printing house, especially in regard to both editions of the tractates Clypeus and Adversus (see below). ${ }^{147}$

compiled partly the tractate Clypeus, obviously from his older, already finished texts, especially the sermons, it seems to me that the date of the dedication adduced by Rothkegel is set too early. Cf. also above n. 113.

${ }^{141}$ Boldan, Úrední jednolistové tisky, 81; Hlobil, "Nejstarší olomoucké knižní dřevořezy," 328.

${ }_{142}$ Boldan, Úrední jednolistové tisky, 81. Cf. also Vobr, "Neznámá olomoucká odpustková listina," 24.

143 Boldan, Úrední jednolistové tisky, 81; Vobr, "Příspěvek" (as n. 16).

144 Vobr, "Př́íspěvek," 10; Hlobil, "Nejstarší olomoucké knižní dřevořezy," 329.

145 Vobr, "Př́íspěvek," 10.

${ }^{146}$ Vobr, "Př́ispěvek," 10. - Greatly at length on commercial activities in the Bohemian Lands developed by the printer and bookseller from Speyer Peter Drach $(\dagger 1504$ ) (on the basis of a fragment of his account-book from the years 1480-1503) Ivan Hlaváček, "Pronikání cizích prvotisků do českých knihoven v 15. stoletî" \{Penetration of Foreign Incunabula into Bohemian Libraries over the Course of the Fifteenth Century\}, in Knihtisk a Universita Karlova. K 500. výroči knihtisku v českých zemich \{Printing and Charles University. On the 500 Anniversary of Printing in the Bohemian Lands\}, edited by Lubomír Vebr (Praha: Univerzita Karlova 1972), 67-95, esp. 86-94.

${ }^{147} \mathrm{I}$ am greatly indebted to my colleague PhDr. Kamil Boldan for the information permitting me to arrive at a more precise conclusion. 
Baumgarten was moreover the only printer working in Olomouc in $1500 .{ }^{148} \mathrm{His}$ activities there began in autumn 1500 with the printing of the anti-Brethren text by Augustin Käsenbrot ${ }^{149}$ Ad eruditum virum magistrum Johannem Nigrum phisicum Tractatus de secta Valdensium; ${ }^{150}$ the print being finished on 29 October $1500 .{ }^{151}$ The print was closely connected through its contents with Institoris' activities in Olomouc. His tractate was taken for a treatise dated 3 June 1500 and addressed to a member of the Unity of Brethren the literary man and renowned physician Jan Černý (Johannes Niger) (about 1456-1530). ${ }^{152}$

${ }^{148}$ The former prototypographer of Brno Mathias Preinlein, who published here only two smaller prints, operated briefly in Olomouc in the year 1499 - Boldan, Úrední jednolistové tisky, 81. Baumgarten was in Olomouc only the second printer in the row - Vobr, "Př́spěvek" 10.

${ }^{149}$ An outstanding Moravian humanist, writer, lawyer and theologian Augustin Käsenbrot (of Olomouc) was born in Olomouc in the year 1467 in a local ethnically German patrician family. He studied in the years 1484-1488 at the University of Cracow, where he received his Bachelor's degree and probably also a Master's. Sent afterwards to the University of Padua he became a doctor in canon law in 1494. From the mid-1490s, he worked as a notary at King Vladislaus' court in Buda. In 1497 he became the canon of the chapter of St. Peter in Brno. He was as of 1498 provost of the Olomouc chapter. In 1506 he became the secretary of King Vladislaus and also the provost of the chapter in Brno. He retired from royal services in 1510 . He has also been known as an enemy of the Unity of Brethren since the 1490s. He died in Olomouc in 1513. About Käsenbrot Nešpor, "O původu” (as n. 73); Josef Truhláŕ, Humanismus a humanistév Čechách za krále Vladislava II. \{Humanism and Humanists in Bohemia in the times of King Vladislav\} (Praha: Česká akademie císaře Františka Josefa pro vědy, slovesnost a umění 1894), 64-69 and 112-114; Karl Wotke, "Augustinus Olomucensis," Zeitschrift des deutschen Vereins für Geschichte Mährens und Schlesiens (further ZDVMS) 2 (1898): 49-71; G. Bauch, "Zu Augustinus Olomucensis," ZDVMS 8 (1904): 119-136; Vincenc Prasek, "Augustin "doktor" a Olomučané" \{Augustin "the Doctor" and the Burghers of Olomouc\}, Ćasopis Matice moravské 26 (1902): 30-42; "Augustinus Olomucensis," in Rukovět humanistického básnictví v Cechách a na Moravě $\{$ Handbook of Humanist Poetry in Bohemia and Moravia $\}=$ Enchiridion renatae poesis Latinae in Bohemia et Moravia cultae. Founded by Josef Truhlár and Karel Hrdina. Continued by Josef Hejnic and Jan Martínek, vol. 1, A-C (Praha: Academia 1966) 111-116; Hlobil, "Nejstarší olomoucké knižní dřevořezy," 345; Eduard Petrů and Ivo Hlobil, Humanismus a raná renesance na Moravě \{Humanism and the Early Renaissance in Moravia\} (Praha: Academia 1992), 35-38; Miloš Kouřil, "Augustin Olomoucký 1467-1513" \{Augustin of Olomouc 1467-1513\}, in Historiografie Moravy a Slezska \{Historiography of Moravia and Silesia\}, vol. 1, edited by Ivo Barteček (Olomouc: Univerzita Palackého, Filozofická fakulta, katedra historie 2001), 13-20. ${ }^{150}$ Edited by Jana Nechutová and Magda Rösslerová, “Augustinus Olomucensis Tractatus de secta Valdensium," Sborník prací filozofické fakulty brnènské univerzity E 30 (1985): 133-147. The edition has been procured on the basis of the only extant Baumgarten copy with regard to the later print of the same tractate in a volume issued in Leipzig in 1512.

${ }^{151}$ Nechutová and Rösslerová, "Augustinus Olomucensis," 145. - According to the opinion of M. Rothkegel, the manifestation of Institoris' humility in regard to the scholastic language used by him in the dedication of the tractates Clypeus and Adversus was actually a response to Käsenbrot's aforementioned epistle written in elegant humanistic wording and rejecting the scholastic method of argumentation (Der lateinische Briefwechsel, 93, incl. n. 3). If this observation is correct, the dedication dated by Rothkegel 30 September 1500 (Der lateinische Briefwechsel, 91), Institoris then refers to a work, whose printing was finished on 29 October 1500. Apart from the not improbable possibility that Institoris knew the Käsenbrot tractate already in manutreatise, there arises the necessity to shift the terminus a quo of Institoris' dedication (and the date of the delivery of the tractates Clypeus and Adversus to printing) to 29 October 1500.

${ }^{152}$ Nechutová and Rösslerová, "Augustinus Olomucensis," 133 and 147. - Jan Černý was an older brother of Lukáš Pražský (about 1460-1528), Bishop (since 1500) and after the death of Tưma Přeloučský (1518) 
The printing of Institoris' tractates Clypeus and Adversus came to a close on 20 April 1501. The said print was the second and at the same time the first more extensive result of Baumgarten's book printing activity in Olomouc. ${ }^{153} \mathrm{On}$ the whole more than one third of the prints issued in the years 1500-1502 from Baumgarten's printing house during his stay in Olomouc, were a product of fruitful collaboration of the said German wandering printer with Institoris. ${ }^{154}$ The print of the tractates Clypeus and Adversus from April 1501 consisted on the whole of 124 folios. ${ }^{155}$

In connection with this print run, Baumgarten provided for the first time in the Bohemian Lands a publisher's offer of a one-sheet. ${ }^{156}$ This advertising fifteen line text measuring $29.5 \times 19 \mathrm{~cm}$ was discovered in already three copies, deposited in Cracow (Biblioteka Jagiellońska), in Munich (Bayerische Staatsbibliothek ${ }^{157}$ ) and the Vatican (Biblioteca Apostolica Vaticana). ${ }^{158}$ The woodcut with an image of St. Wenceslas with two angels, which is in the lower half of the one-sheet, was used by Baumgarten already before on the title leaf of Käsenbrot's tractate. ${ }^{159}$ All three preserved copies of the advertising one-sheet

the highest representative of the Unity of Brethren. Lukáš Pražský established himself at the beginning of the sixteenth century as the most significant theologian of the Unity as well. - Considering the personality of Jan Černý see G. [Gustav] Gellner, “Jan Černý a jiní lékaři čeští do konce doby jagellovské” \{Jan Černý and Other Czech Physicians until the end of the Jagiellonian age\}, in Véstnik Královské české společnosti nauk. Trída filosoficko-historická, ročnik 1934 \{Journal of the Royal Bohemian Academy of Sciences. Class of Philosophy and History for the year 1934$\}$ (Praha: Královská česká společnost nauk 1935), section III, 1-176. As to the epistle of Käsenbrot, which is at the same time an important source for the biography of Jan Černý, see Gellner, "Jan Černý," 16-29. It also follows from the epistle that Käsenbrot had been a patient of Černý and that he ascertained that Černý was a member of the Unity of Brethren only in the spring of the year 1500, when he met him in the colony of houses of the Brethren in Prostějov (germ. Proßnitz) (Gellner, "Jan Černý," 19). The epistle from the year 1500 was the first one from the file of Käsenbrot's printed polemical antibrethren epistles addressed to Černý. The other two followed in 1501, the last one in 1503 . Černýs Latin answers to the epistles remained in manutreatise form and are not extant. Only preserved are translations into Czech of his answers given to the two first epistles by Käsenbrot. These epistles are annexed in the translation into Czech as well. The translations in question were established before 1561 (Gellner, "Jan Černý," 22-23). - G. Gellner is of the opinion that the Käsenbrot epistle may have been released before going to press at Baumgarten's for approbation to the inquisitor Institoris. I find this improbable. According to Gellner, the print did not come into the hands of the addressee in Prostějov but in the spring 1501 by an around about way through Moravská Třebová (germ. Mährisch Trübau) with an almost half year delay (Gellner, "Jan Černý," 27).

${ }^{153}$ Vobr, "Príspěvek," 11.

${ }^{154}$ Vobr, "Př́spěvek," 11-15. See in more detail below. - Segl, "Deutsche Dominikaner," 112, wrongly (or with too much exaggeration) states that Clypeus was thicker than the Hammer of Witches. Cf. also above n. 139. 155 Vobr, "Př́íspěvek," 11 , nr. 1.

156 Vobr, "Př́śsěvek," 12, nr. 5, and 14, nr. 12; Vobr, “Olomoucká odpustková listina” (as n. 17); Boldan, Úrední jednolistové tisky, 83-84.

157 The copy deposited in the Bavarian State Library in Munich has been edited as a facsimile by Schottenloher, Eine Bücheranzeige (as n. 17).

${ }_{158}$ Boldan, Úredni jednolistové tisky, 72-73 and 83-84.

${ }^{159}$ Boldan, Úrední jednolistové tisky, 72-73 and 83-84. Cf. also above, esp. n. 149 and 150. - Especially considering this wood engraving and in general the motif of the image of St. Wenceslas with angels Hlobil, "Nejstarší olomoucké knižní dřevořezy," 328-330, 335-336, 339-341 and 353-358. 
were printed on clean reverse sides of the one-sheets of the indulgence deed of the papal legate Cardinal Pietro Isvalies $(† 1511)$ in connection with his anti-Turkish campaign taking place in the beginning of $1501,{ }^{160}$ which remained unsold by Baumgarten. The Isvalies indulgence deed is preserved in two identical versions so far as the text is concerned. ${ }^{161}$ The offer one-sheet is undated, but it is certain that it was printed together with the first edition of the tractates Clypeus and Adversus, the sale of which was supposed to be further or only a little later. ${ }^{162}$

The advertising bookseller broadsheet represented in the Bohemian Lands a rather unusual phenomenon at the very beginning of the sixteenth century. ${ }^{163}$ The following is a later recorded amusing story which bears unmistakable testimony to this assertion. It came to the attention of Tůma Přeloučský, one of the participants in the Olomouc debate, intelligence about the one-sheets being posted up, which contained invectives directed at the Unity of Brethren and which were connected with Institoris. Tưma, who did know about this new advertising medium was led, evidently by his own opinion, to believe that Institoris was posting up on church doors outrageous sheets. ${ }^{164} \mathrm{He}$ wrote in 1502 to Lord Albrecht of Sternberg: "Nadarmot' tehdy i pan doktor, vyhledavač kacirưv, usiluje i listy hánlivé na kostelních dverích lípá, chtě nás opraviti a z bludu vyvésti..." IIn vain the Doctor, this Doctor of heretics, is working and posting up outrageous sheets on the church doors, trying to correct us and make us free from error\}. ${ }^{165}$

As demonstrated by T. Herzig, Institoris was for a greater part the author of the pamphlet Stigmifere, ${ }^{166}$ whose Latin version came out of the printing office of the printer Baumgarten

${ }_{160}$ Boldan, Úrední jednolistové tisky, 84-85.

${ }^{161}$ Boldan, Úrední jednolistové tisky, 74-77 and 85-86; Vobr, "Příspěvek," 12, nr. 5, and 14, nr. 12.

162 Boldan, Úrední jednolistové tisky, 85.

163 Boldan, Úrední jednolistové tisky, 84, remarks, however, that the oldest bohemical advertising sheet originated "in the time, when the printers in German countries somehow began to retreat from the use of the one-sheet medium to propagate the news....".

${ }^{164}$ Boldan, Úredni jednolistové tisky, 85-86. - The fifteen-line text of the sheet runs as follows: "In defensione[m] Catholice fidei sancteq[ue] Romane ecclesie aduersus Pickarditos waldenses cuncta [christi]anorum regna sparsim in odiu[m] cleri ac ecclesiastice potestatis eneruatione [m] pestifera co[n]tagione inficientes: Opus perutile sermonum. nouiter ex c[o]missione moderni. Summi pontificis collectum, pro informatione predicatorum, declarans. q[uam] ta[n]tummodo sub obedientia ip[s]ius Sancte Romane et apostolice sedis colitur et venerat[ur] illa vera et vnica fides sine qua nemo saluari potest. Si quis leui pretio conparare velit supra notatum opus inue[n]iet in hospitio..." - Czech translation Vobr, "Olomoucká odpustková listina," 27.

165 Ti̛my Přeloučského spis, 67-68. Sokol, Vavřinec Krasonický, 66 and 101, expounds Tůma’s communication in the sense that Institoris, after not having persuaded the representatives of the Brethren about their errors in the dispute, at least posted up on the cathedral doors sheets directed against the Unity of Brethren. Tůma’s error was taken over by Hlobil, "Nejstarší olomoucké knižní dřevořezy," 340, and recently almost literally by Hlaváček, "Inkvizitor," 78. Cf. also Boldan, Úřední jednolistové tisky, 85, esp. n. 24. K. Boldan points out that the very old Institoris would post up offers of his tractate, which were no doubt attractive but not real (also Boldan, Úrední jednolistové tisky, 84). On the other hand, the idea of the inquisitor fixing his authorization on the church door is wholly mechanically connected with Institoris by recent research - see G. Jerouschek, "Heinrich Kramer," 124.

${ }^{166}$ Herzig, Christ, 158-159. See also above n. 22. 
in 1501 as well, ${ }^{167}$ with the date of 16 September, ${ }^{168}$ and evidently delivered to press not until several weeks later after 20 May of the same year. ${ }^{169}$ The title woodcut of the print Stigmifere represents Calvary with three Marys. ${ }^{170}$ This title leaf is in all probability a copy of the title page of a contemporary Nuremberg print, which is a product of the workshop of Albrecht Dürer ${ }^{171}$ and which was copied by the relatively competent wood engraver Baumgarten. ${ }^{172}$

The same wood engraving as in the print Stigmifere was on the title side of the only German print arranged by Baumgarten in Olomouc. ${ }^{173}$ It was the title Wunderbarliche

\footnotetext{
${ }^{167}$ For the edition of the pamphlet see Herzig, Christ, 293-320.

${ }^{168}$ Herzig, Christ, 320. Cf. also Hlobil, "Nejstarší olomoucké knižní dřevořezy," 328. Very inexactly about this print Segl, "Deutsche Dominikaner," 113.

${ }^{169}$ Only afterwards Insitoris knew about the end of Columba di Rieti, who died on 20 May 1501 in Perugia - Herzig, Christ, 313, n. 140.

${ }^{170}$ Reproduction according to the copy deposited in Warsaw (Biblioteka uniwersytecka) Hlobil, "Nejstarší olomoucké knižní dřevořezy, “ 331 (picture nr. 2); Herzig, Christ, 283 (Fig. 2).

${ }^{171}$ See the title page of the treatise Spiritualium personarum feminei sexus facta admiratione digna, issued in print in Nuremberg. The commentary to this woodcut, showing "three women kneeling before Christ on the Cross", is provided by Herzig, Christ, 284 (Fig. 3). See as well the digitalized version of the copy of the above-mentioned treatise in the Bavarian State Library in Munich (Bayerische Staatsbibliothek, further BSB) - https://books.google.cz/books?id=QvHAzHIRpk4C\&printsec=frontcover\&hl=cs\&source=gbs_ge_summ ary_r\&cad $=0 \# \mathrm{v}=$ onepage $\& \mathrm{q} \& \mathrm{f}=$ false $(24.7 .2017)$. T. Herzig refers to the Nuremberg printer Hieronymus Höltzel as the originator of this print (first mention in 1500, $\dagger$ after 1532). Both Herzig and BSB date the print to 1501. The making of the copy of the title page of the print Spiritualium in the Olomouc Stigmifere shifts the terminus ad quem of the origin of the print Spiritualium to a time shortly after the middle of the year 1501. - Herzig, Christ, 237-238, is of the opinion, however, that the title page of the anonymous print Spiritualium is of later date than the title page of the Olomouc print of the Stigmifere. She states the grounds for it arguing that in spite of the fact that the Olomouc woodcut is considerably worse done and lacks many details, which were not essential for Institoris and Baumgarten, this is the reason it may be considered older. At the same time T. Herzig maintains, that the woodcut used on the Olomouc Latin (and German) edition of the Stigmifere was arranged in Dürrer's workshop in Nuremberg, with which Institoris should have maintained contact. Herzig states further with reference to the information provided by the British Library, that the German version of the Spiritualium, arranged by the printer H. Höltzel evidently in 1501 as well, shows the same title page as the German version of the Stigmifere issued in Olomouc on 20 September 1501 (Herzig, Christ, 238, incl. n. 27). This creates, however, the impression of a nonsensical assertion (cf. Vobr, "Př́spěvek," 13, nr. 7, and lower notes 176 and 177). - Considering the priority of the title page of the Spiritualium as opposed to the title page of the Olomouc Stigmifere, I am relying on the synonymous opinion of K. Boldan from the National Library of the Czech Republic in Prague, obviously the best contemporary Czech specialist in early European printing, to whom my thanks go for his expert advice. - The art historian Hlobil, "Nejstarší olomoucké knižní dřevořezy," 332, stated that the woodcut with three Marias in Stigmifere testifies to "Baumgarten's contact with the progressive south German environment during his stay in Olomouc". The above-mentioned woodcut is, according to Hlobil, not of the first rate quality, but shows marks of an advanced style, which cannot be ascertained by the proper engravings done by K. Baumgarten (Hlobil, "Nejstarší olomoucké knižní dřevořezy," 348, n. 50). This appreciation of Hlobil corresponds well with the above-mentioned opinion of K. Boldan.

${ }^{172}$ See e. g. Hlobil, "Nejstarší olomoucké knižní dřevořezy," 328-330; Boldan, Úřední jednolistové tisky, 86. ${ }^{173}$ Vobr, "Př́spěvek," 13, nr. 7.
} 
geschicht vonn geystlichen weybes personenn, dated 20 September $1501 .{ }^{174}$ It was doubtless a German translation of Stigmifere arranged by Institoris and which was finished in Baumgarten's printing office only several days after the edition of the original Latin version of the treatise. ${ }^{175}$ In the beginning of the nineteenth century, the German bibliographer Georg Wolfgang Panzer (1729-1802) stated that the print was in his collection. ${ }^{176}$ It is lost at present and another one has not been found as yet. ${ }^{177}$

Baumgarten arranged a second edition of the tractates Clypeus and Adversus on March 20 1502. This edition was printed completely new ${ }^{178}$ and consisted of 116 folios, that is eight folios less than the extent of the first edition. ${ }^{179}$ The advertising campaign to support the first edition of Institoris' tractates was obviously successful, and the publication lived to see another edition. From the seven works of Institoris published in print, it was the thesis extant publication which lived to see the second greatest expansion and success after the Hammer of Witches. The second edition of the tractates Clypeus and Adversus, which had as it seems a higher circulation than the first one, is extant in dozens of copies. ${ }^{180}$ Both editions circulated obviously in the first ten years of the sixteenth century throughout Central Europe, which is borne testimony by the fact of their being handed down in many, mainly monastic, libraries in the Czech Republic, Slovakia, Hungary, Germany, Poland, Romania, the Netherlands and Italy. ${ }^{181}$ The commercial success of the prints with the tractates Clypeus and Adversus was obviously due to the somewhat higher efficiency and better equipment of Baumgarten's Olomouc printing office in comparison with the then Bohemian and Moravian printing houses and perhaps the in advance ensured sales, especially in Silesia. ${ }^{182}$

\footnotetext{
${ }^{174}$ Vobr, "Př́íspěvek," 13, nr. 7.

${ }^{175}$ Herzig, Christ, 239-240, indicated on the contrary, that the print Wunderbarlithe [sic] geschichten die do geschehen synt von geystlichen wybs personen in disen Joren, which had been arranged in Strasbourg probably in 1502, cannot be most probably taken for a German translation of the pamphlet Stigmifere, but for a further edition of the translation into German of the treatise Spiritualium.

${ }^{176}$ Herzig, Christ, 229. Cf. also Vobr, "Př́spěvek," 13, nr. 7.

177 Vobr, "Př́spěvek," 13, n. 7 and 15, n. 4.

${ }^{178}$ A. Kubíček, who used the second edition, writes in this connection that Institoris' tractates "just swarm with misprints" (Kubíček, "Jindřich Institoris," 121, n. 9). The question is how far these misprints are to be attributed to the ignorance of the author alone - cf. above n. 151. Considering the differences between both editions cf. also Isidor Zahradník, "Jindřich Institoris" \{Henry Institoris\}, Časopis katolického duchovenstva 63 (1902): 509.

${ }^{179}$ Vobr, "Př́íspěvek," 12-13, nr. 6. Cf. also 11, nr. 2.

${ }^{180}$ Vobr, "Př́spěvek," 12-13, nr. 6.

${ }^{181}$ Herzig, Christ, 114. Cf. also Vobr, "Př́íspěvek," 12-13, nr. 6.

182 Boldan, Úrední jednolistové tisky, 81; Vobr, "Příspěvek," 11.
} 
The second edition of the tractates Clypeus and Adversus was the last dated print, arranged by Konrad Baumgarten in Olomouc ${ }^{183}$ before his departure to Vratislav during the year 1502 or at the beginning of the following year. ${ }^{184}$

The fruitful collaboration between printer Baumgarten and Inquisitor only lasted approximatively one and a half years. Nevertheless, it resulted in five documented, formally and with regard to the contents, heterogeneous prints. Moreover, Baumgarten's woodcut with escutcheons of Pope Alexander VI and Heinrich Institoris, used in the first and second edition of the tractates Clypeus and Adversus, appeared, certainly not by chance, already in Käsenbrot's Tractatus, through which the wandering printer started his career in Olomouc. Even the Tractatus of Käsenbrot and both publications of the tractates Clypeus and Adversus were doubtless the most important Baumgarten prints arranged in Olomouc. ${ }^{185}$

After Baumgarten's departure from Olomouc, Institoris ceased his publishing activities, at least because there was for some time no existing printer in either Olomouc or Moravia. The third one among the representatives of this trade was Liborius Fürstenhain from Heiligenstadt near Vienna. His activity in Olomouc was merely reduced to the printing of one treatise in August 1504. ${ }^{186}$

The debate which took place in Olomouc with Krasonický and Tůma Přeloučský was not the only dispute with the representatives of the Unity of Brethren carried out by Institoris during the course of his activities in Moravia. In his late treatise $O$ učených \{On the Learned\} (1530) Krasonický recalls a dispute which Institoris had with Václav (Wenceslas), a scribe in Rychnov. He allegedly defeated Institoris "forcing him to be silent"

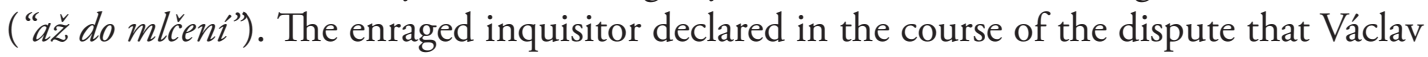
wass worse than the Devil. ${ }^{187}$

Not long after his arrival in Moravia, Institoris fell out with the Franciscan Observants, who constituted about the year 1500 the strongest mendicant community in the Bohemian Lands and successfully competed mainly with the Dominicans. ${ }^{188}$ After the printing of the tractates Clypeus and Adversus, Institoris laid these works fictitiously before the Franciscans

\footnotetext{
${ }^{183}$ Vobr, "Př́íspěvek," 11-15, names the year 1501 as the date of all Baumgarten's prints in Olomouc except the first one from October 1500, which he classifies as a incunabula, and the last one from March 1502.

${ }^{184}$ Baumgarten departed from Olomouc between 20 March 1502 on finishing the print of the second edition of the tractates Clypeus and Adversus and 10 February 1503, when becoming a citizen of Vratislav - Hlobil, "Nejstarší olomoucké knižní dřevořezy," 329 and 347, n. 23.

${ }^{185}$ Hlobil, "Nejstarší olomoucké knižní dřevořezy," 339.

${ }^{186}$ Hlobil, "Nejstarší olomoucké knižní dřevořezy," 329.

187 Sokol, "Vavřinec Krasonický," 65 and 101, n. 87; Justová, Tưma Př́loučský, 77; Segl, "Heinrich Institoris," 125. - The scribe Václav gave an answer to the reproach of being "worse than the Devil" by paraphrasing the words of Jan (Joannes) Hus (according to Vavřinec Krasonický, O učených, in Českobratrská výchova, 85): "Ty si selhal v svou hlavu a hned toho dovedu: Ďábel hrěši od poćátku světa, ale já od padesáti let; protož neprávě smís krivdu svědčiti, že bych byl horši než čert etc." \{You have lied and I shall immediately bring the proof of it: The Devil has sinned since the origin of the world, I since the age of fifty, this is why you have no right to state unjustly that I am worse than the devil, etc.\}

${ }^{188}$ Hlaváček, "Inkvizitor,” 79.
} 
of Olomouc. They considered it a provocation because the Inquisitor had begun already earlier an investigation into an alleged heresy existing in their order. ${ }^{189}$

Concerning the activities developed by Institoris in the Bohemian Lands there is information in two contemporary Franciscan chronicles. The older one entitled De novella plantatione provincie Austrie, Bohemie et Polonie, quo ad fratres minores de observantia Cronica designates Institoris sarcastically as a wandering friar ("vagus religiosus doctor bullatus"), who did not attain his doctorate in theology in an orderly way at University, but who was only being promoted by a papal bull. ${ }^{190}$ Apart from this it is stated here that Institoris held at that time, in 1500, the office of a preacher in the Olomouc parish church of St. Maurice. ${ }^{191}$ The author of the aforementioned chronicle was the German Franciscan-Observant from the Rhineland Eberhard Ablauff ( $†$ 1528), who may have written it in 1505 in the Olomouc Franciscan convent. ${ }^{192}$ The above-named author stated further that Institoris had as an inquisitor persecuted the Franciscans in many countries and did so in Olomouc as well. The Olomouc Franciscans defended themselves, however, before Bishop Thurzo as well as in front of the local City Council. ${ }^{193}$

Institoris' work in Moravia is dealt with relatively fully and at some places ironically in the Chronica Fratrum Minorum de Observancia Provincie Bohemie, which originated sometime in the years 1510-1521. ${ }^{194}$ Its author was Michael from Carinthia († 1534), who was in the years 1526-1528 and 1531-1533 the provincialis of the Bohemian Franciscans. ${ }^{195}$ The inquisitor and Dominican Henricus Institoris is in the aforementioned chronicle designated as an "old and foolish apostle" ("antiquus et delirus apostolus"), but not as an apostle of Christ ("apostolus sed non Christi") and the greatest persecutor of the Franciscans ("nostri ordinis maximus persecutor"), who had persecuted them unfairly as the Jews had done to Christ ("minus iuste sicut iudei Christum"). ${ }^{196}$ The author states further that Institoris had operated in Olomouc as a preacher in St. Maurice church. ${ }^{197}$

The time, place and year of Heinrich Institoris' death are not included amongst the dates, which have been presented in the existing research with absolute certainty. Older Czech researchers primarily stated that Institoris left Moravia after 1502 and passed away nobody knows where. ${ }^{198}$

\footnotetext{
${ }^{189}$ Hlaváček, Die böhmischen Franziskaner, 115.

${ }^{190}$ Hlaváček, "Inkvizitor," 79.

${ }^{191}$ Hlaváček, "Inkvizitor," 79, n. 43.

192 Petr Hlaváček, „Eberhard Ablauff de Rheno († 1528) im Geistesleben der böhmischen Franziskaner am Anfang der Frühen Neuzeit", in Leben und Alltag in böhmisch-mährischen und niederösterreichischen Klöstern in Spätmittelalter und Neuzeit, edited by Heidemarie Specht and Tomáš Černušák (Brno and St. Pölten: Diözesanarchiv 2011) 136-146.

${ }^{193}$ Hlaváček, "Inkvizitor," 79.

${ }^{194}$ Hlaváček, Die böhmischen Franziskaner, 10.

${ }^{195}$ Hlaváček, Die böhmischen Franziskaner, 9-10; Hlaváček, "Inkvizitor," 79.

${ }^{196}$ Hlaváček, "Inkvizitor," 79-80, incl. n. 44.

${ }^{197}$ Hlaváček, "Inkvizitor," 80, n. 44; cf. Hlaváček, "Apostolus," 47-48.

198 Typical Jireček, Rukovět', 298; Včk, "Institoris” (as n. 8). Cf. also Hlaváček, "Inkvizitor,” 80. This opinion can be considered thus far justified, for there were not known any reports of a bohemical provenance about
} 
The view of J. Hansen, that Institoris died in 1505 in Moravia, gradually began to prevail in Czech literature as well. ${ }^{199}$ Hansen fixed the place and year of Institoris' death based on a relatively late report (from around 1530) of a Dominican from Pirna Johannes Lindner (born around 1450, $\dagger$ around 1530), who wrote under the name Monachus Pirnensis. ${ }^{200}$ According to this report, Institoris known as Heinricus Kremer, a Black friar from Cologne [sic], died in 1505 in Moravia. In accordance with this intelligence, the concerned wrote against the Waldensians, wrote a book against witchcraft and was endowed with the authority to search out heretics and investigate sorcery (zöbrey). Lindner's report further stated that Institoris had been initially active in the (Duchy of) Nisa in Silesia, that he had allegedly in 1493 preached in Prague before King Vladislaus in Latin and German and that he had been in Olomouc in Moravia ad s. Mariam Magdalenam and died there. ${ }^{201}$ This daselbst must have been a reference to Olmyncz, and not to Merhen.

Overlooking the reference to Institoris' person to Cologne, which obviously is based upon the Cologne approbation from May 1487 reprinted in the introduction to the Hammer of Witches beginning with its second edition, ${ }^{202}$ there is no possibility whatsoever to furnish proof of his operations in Silesia, moreover with an exact determination in Nisa in Upper Silesia. ${ }^{203}$ One cannot, however, exclude a short stay of Institoris in the town of Nisa or in the Duchy of Nisa, in all probably at the end of the 1460s or at the beginning of the 1470s. The town of Nisa ${ }^{204}$ and the Duchy of Nisa belonged (with short interruptions) since the second half of the fourteenth century to the property of the Bishop of Vratislav. In the years 1468-1482 the bishop's seat was held by Rudolf of Rüdesheim, with whom Institoris had come into contact at the end of the 1460s. ${ }^{205}$ The naming, in contrast, of the year 1493 as the date of the encounter of King Vladislaus Jagiello with Institoris in Prague (only as a preacher, not as a participant in a dispute) is as nonsensical as referring to the years 1499 and 1500. In 1493 King Vladislaus had not been, it is as simple as that, in the capital city of the Kingdom of Bohemia. ${ }^{206}$

\footnotetext{
Institoris after 1502.

${ }^{199}$ Hansen, Quellen, 394-395, incl. n. 7. - Cf. Sokol, "Vavřinůc Krasonický," 66; Kočí, Čarodéjnické procesy, 14; Šindeláŕ, Hon na čarodějnice, 145.

${ }^{200}$ Hansen, Quellen, 394-395, incl n. 7. For the full wording of the report see Schnyder, Malleus Maleficarum, 73 , nr. 80.

${ }^{201}$ Schnyder, Malleus Maleficarum, 73, nr. 80.

${ }^{202}$ Kramer (Institoris), Der Hexenhammer, 23-24 and 107-116. Considering the genuineness of the approbation, see recently The Hammer of Witches. A Complete Translation of the Malleus Maleficarum. Translated by Christopher S. Mackay, 1. ed. (Cambridge: Cambridge University Press) 2009, 9-10. C. Mackay refuted thus the opinion of J. Hansen (Joseph Hansen, "Der Malleus Maleficarum, seine Druckaugaben und die gefälschte Kölner Approbation von Jahre 1487," Westdeutsche Zeitschrift für Geschichte und Kunst 17 (1898): 119-168), that the approbation was falsified. This Hansen's opinion has been taken over by the greater part of the later literature.

${ }^{203}$ Hansen, Quellen, 394-395, n. 7. Cf. also Schnyder, Malleus Maleficarum, 73, nr. 80, n. 198.

${ }^{204}$ Handbuch der historischen Stätten. Schlesien, edited by Hugo Weczerka (Stuttgart: Kröner 1977), 331-338.

${ }^{205}$ Cf. above notes 40 and 41.

${ }^{206}$ See above n. 103.
} 
The church consecrated to St. Maria Magdalene does not actually exist in Olomouc. This problem with the nonexistence of the church, if you like of the consecration to St. Maria Magdalene in Olomouc, was solved by J. Hansen almost through association when making reference to Brno, obviously the nearest Moravian royal city of importance with the corresponding patrocinium. ${ }^{207}$ He thus made Brno for many later authors the last place of sojourn, death and last repose of Institoris. ${ }^{208}$ This can to be viewed as an immense paradox, that a sacred object with an above-mentioned patrocinium existed in Olomouc at the time of Institoris' stay. The St. Maria Magdalene church may have belonged to the three oldest Olomouc churches. It was situated within the area of the castle of Olomouc, near the St. Wenceslas cathedral. It was erected already in the middle of the eleventh century, that is before the foundation of the bishopric of Olomouc (1063). The first reference to it can be ascertained in a deed issued by King Přemysl Otakar II (Ottokar II of Bohemia) in 1267. It was last mentioned as a chapel in 1541, when the mortal remains of the Bishop of Olomouc Bernard Zoubek of Zdětín ( $† 12$ March 1541), an early deceased successor to Bishop Stanislav I Thurzo, were exhibited here before the burial after the transport from Kromerryiž. The chapel was uncovered during archaeological research conducted at the Olomouc fortress in the 1980s and 1990s. ${ }^{209}$

If there were another source at hand, a highly alluring hypothesis may have arisen ${ }^{210}$ that the burial place of Institoris was the aforementioned chapel at the Olomouc castle. Thank God, this is not so... We must be satisfied with an uncertain hypothesis, that the chapel of St. Maria Magdalene may have been, apart from the St. Maurice church, the next place in Olomouc where Institoris delivered his sermons. ${ }^{211}$

P. Hlaváček discovered several years ago a very reliable report about Institoris' death and the place where it occurred in the above-mentioned Chronicle of the Bohemian Franciscan province due to Michael of Carinthia. According to this intelligence, Institoris retired to the episcopal chateau in Kromerryizz ("ipsa interiit in arce Cremsyer"), where he suffered "a bad death" ("mala morte"). ${ }^{212}$ The year of his death is not exactly stated there. ${ }^{213}$ It cannot be deduced with absolute certainty, in my opinion, that Institoris was buried in the Kroměríz

\footnotetext{
${ }^{207}$ Hansen, Quellen, 394-395, n. 7.

${ }^{208}$ Schnyder, Malleus Maleficarum, 73, nr. 80, n. 199.

${ }^{209}$ Vít Dohnal, Tři nejstarši olomoucké kostely. Olomoucký hrad v raném stréedověku \{The Three Oldest Churches in Olomouc. The Olomouc Castle in the Middle Ages\}, vol. III (Olomouc: Archeologické centrum Olomouc 2006), 27. - To the existence of the St. Maria Magdalene chapel in Olomouc in Institoris' time attention was drawn already by Hlobil, "Nejstarší olomoucké knižní dřevořezy," 352, n. 134.

${ }^{210}$ I must admit to have partly succumbed to this hypothesis - Petr Kreuz, "Čarodějnické procesy a právo" \{Witch Trials and Law\}, in Jindřich Francek, Carodějnické př́běhy \{Histories of Witches\}, (Praha: Paseka 2005), 14.

211 Schnyder, Malleus Maleficarum, 73, nr. 80.

${ }^{212}$ Hlaváček, "Inkvizitor," 79-80, incl. n. 44; cf. Hlaváček, "Apostolus," 48.

213 The report only mentions an uncertain time (eodem tempore), which refers first of all to Institoris operating as an inquisitor in Olomouc (Hlaváček, "Inkvizitor", 79-80). P. Hlaváček nonetheless considers 1505 as the year of death (Hlaváček, "Inkvizitor", 80). Cf. also Hlaváček, "Apostolus," 48.
} 
collegiate St. Maurice church, however, it can be considered highly probable. ${ }^{214}$ The author of the above-mentioned chronicle knew nevertheless (contrary to the Black friar from Pirna Lindner) from the autopsy the situation in the diocese of Olomouc in the first third of the sixteenth century, despite the fact that he did not arrive in Olomouc until a few years after Institoris' passing away. The above-mentioned death place fits rather sufficiently into the framework of known circumstances of Institoris' activities in the diocese of Olomouc. It is explicitly worth mentioning that he stayed at the chateau in Kromerřizz at least at the time of his arrival in Moravia. ${ }^{215}$

Notwithstanding the fact that the year 1505 for the date of the Institoris' death seems extremely likely, it cannot be wholly overlooked that it is only stated in an unreliable, relatively late and territorially distant report by Johannes Lindner. ${ }^{216}$ It can only be said with absolute certainty that the last reliable intelligence about Institoris' activities comes from March $1502^{217}$ and that by the second decade of the sixteenth century he was no longer among the living... ${ }^{218}$

${ }^{214} \mathrm{P}$. Hlaváček deduces the location of the burial place from a securely established place of death with an addition, "that his tombstone has not been handed down to us" (Hlaváček, "Inkvizitor," 80). Cf. Hlaváček, "Apostolus," 48: "In diesem Fall wurde er [Institoris - n. P. K.] sicher [! - n. P. K.] in der dortigen Kollegiatskirche St. Moritz beerdigt; sein Grabstein ist allerdings nicht erhalten." - On the other hand, the words "predicator ecclesie parochialis sancti Mauricii" (Hlaváček, "Inkvizitor," 80, n. 44) in the chronicle intelligence refer doubtless to St. Maurice church in Olomouc.

215 See above n. 121.

216 See above, esp. n. 200.

217 See above n. 178 and 179.

218 This is also corroborated by the report in the above-mentioned Franciscan Chronicle Michael's from Carinthia, which originated at some point in the years 1510-1521. Institoris' death is described here as an event, which in the opinion of the chronicler took place only recently. - Hlobil, "Nejstarší olomoucké knižní dřevořezy," 352, n. 134, drew, with respect to the typewritten regesta elaborated by the Olomouc archivist Václav Nešpor, attention to the entry in the previously quoted Olomouc Liber antiquus contractum et testamentorum 1492-1593 (see n. 73) concerning the imprisonment of a certain Kilian Kristin for having outraged the community "wegen des predigers sancte Mauricii". Nešpor identified this unnamed preacher with Institoris. There is no other reason for this opinion than that Institoris held the office of preacher St. Maurice church in Olomouc at the turn of the sixteenth century. - The quoted Brethren polemic tractate Odpovéd' na listy doktora Augustina, let us say Známo bud'všem, which originated in the end of the year 1507 and was printed in the following year in Litomyšl, does not make mention of Institoris as being deceased, but as a colleague of the (living) Augustin Käsenbrot (see above n. 124; cf. also Hlaváček, "Apostolus", 48-49). Since the Brethren's Litomyšl lay hardly $90 \mathrm{~km}$ from Olomouc and at a distance of $140 \mathrm{~km}$ from Kroměříž, the news of Institoris' death could not have arrived at the end of 1507, otherwise it would have been noted by the leaders of the Unity of Brethren with even more satisfaction than by the Franciscans. Hence it follows that the Bohemian Brethren either interrupted all communication with Institoris after the tractates Adversus and Clypeus had been published, or the Inquisitor was still alive in $1507 \ldots$ 


\section{Conclusion}

In contrast to the participation in witch trials in the diocese of Konstanz in the first half of the 1480s or his activities in Innsbruck in $1485,{ }^{219}$ the operations of Heinrich Institoris in Olomouc and if you like in the Olomouc diocese should be viewed as entirely negative. Nonetheless is to be asked how far this ambivalent picture of his activities in the last years of his life was a product of the milieu and the circumstances in which he found himself, which he was forced to react to and to which he had, at least partly, to adapt to.

Not long after arriving in Olomouc the recently appointed inquisitor in Bohemie Regno ac prouincia Moramie understood that it was impossible to persecute or oppress the Utraquists in the Bohemian Lands in whatever manner, as he had done in a broader Central European context at the turn of the 1470s after the declaration of the crusade against George of Podebrady and this in spite of the fact that he continued to reject the Utraquist Holy Communion $^{220}$ and in spite of the strong aversion of Pope Alexander VI for all "Bohemian heretics". ${ }^{221}$ It was equally out of the question, even in predominantly Catholic Moravia, to initiate direct persecution of the members and supporters of the de iure illegal Unity of Brethren. Institoris went at length into an account of the exceptional character of the Bohemian (and Moravian) milieu influenced fundamentally by the Hussite movement. There was not merely a two creed situation with Catholics and Utraquists in the Czech Lands. The opponents of the Catholic Church were not only Utraquists (ready to compromise if need be), but more moderate and more implacabe members of the Unity of Brethren. Although Institoris was not well disposed towards open disputes on questions of the faith, he was forced by necessity to admit them in a form, which the opponents were accustomed to and which had no counterpart at the turn of the sixteenth century in the other worlds of Christianity. ${ }^{222}$ While, the Waldensian communities in Western Europe were in secret or in underground (expressed in the own words of Institoris drawn from Opusculorum as subterraneos hereticos), ${ }^{223}$ the Unity of Brethren operated quite openly in the Bohemian lands at the end of the fifteenth century. The breve from 5 February 1500, which laid an emphasis, apart from other problems, on the preacher's activities was already a reaction provoked by the personal acquaintance with the conditions prevailing in the Bohemian Lands in the spring of 1499 . Institoris soon found out that the tactics he was accustomed to using as an inquisitor, ${ }^{224}$ would be in greater part a failure under the conditions reigning in the Bohemian Lands at that time. Finally he came to the conclusion, that the only means, with which it would be possible to fight under the actual state of affairs against the

\footnotetext{
${ }^{219}$ Kramer (Institoris), Der Hexenhammer, 50-63.

${ }^{220}$ Molnár, "Protivaldenská polemika," 154.

${ }^{221}$ Zikmund Winter, Život církevní v Čechách. Kulturně-historický obraz z XV. a XVI. století \{Church Life in Bohemia. A Cultural and Historical Picture from the XV and XVI Centuries\}, vol. I, (Praha: Česká akademie císaře Františka Josefa pro vědy, slovesnost a umění 1895), 34. Cf. above n. 83.

${ }^{222}$ Molnár, "Protivaldenská polemika," 153-154.

${ }^{223}$ Molnár, "Protivaldenská polemika," 154 and 166, n. 19. Cf. Hlaváček, "Apostolus," 45-46.

${ }^{224}$ Jerouschek, "Heinrich Institoris," 124-125.
} 
Unity of Brethren ("Bohemian Waldensians"), were represented by preaching and literary activities, if need be an exercise of partial influence upon the political situation. ${ }^{225} \mathrm{He}$ also soon grasped the necessity to hold public disputes with the representatives of the Unity. Soon after his arrival, the Olomouc St. Maurice (not the Dominican monastery church of St. Michael), this being the place where he delivered his sermons, became one of the largest and most imposing parish churches in the Catholic bastion of the Bohemian Lands.

Due to a happy coincidence of circumstances he was able to use bookprinting for the spreading of his anti-Brethren polemics for a certain time with success, and this specifically, for the conditions prevailing in the Bohemian Lands at that time, in the extremely efficient ${ }^{226}$ printing office of Konrad Baumgarten, whose Olomouc publishing program Institoris filled for more than a third part. He was even advertised in form of publisher's advertising prints, being generally the first author in the Czech Lands. Institoris also worked hard at creating something like "an action plan" for the Catholic nobility ${ }^{227}$ and other Catholic personalities and dignitaries in the Bohemian Lands. ${ }^{228} \mathrm{He}$ was anxious to represent Italy to the Catholic oriented, but as concerns religion, often half-hearted humanists of the Jagellonian age, as not only the cradle of humanism, but also as a country where the saints Lucy Brocadelli, Stephana de Quinzanis and Colomba of Rieti lived, who perform uncommon and dazzling miracles. From this point of view, Institoris' pamphlet Stigmifere - was the only work of his also translated during his lifetime into a vernacular language and in this form published in print - but to Catholic readers in Moravia, first of all those in Olomouc. ${ }^{229}$ Especially from certain passages of the tractate Adversus, it is apparent that the final purpose of Institoris' literary activities and of his preaching was to incite above all the Moravian Catholic nobility ${ }^{230}$ and other influential Catholic personalities and dignitaries in the Bohemian Lands to take more decided steps against the Unity of Brethren and to finally adopt efficient measures to defeat the "Bohemian Waldensians". ${ }^{231}$

\footnotetext{
${ }^{225}$ Hlobil, "Nejstarší olomoucké knižní dřevořezy," 339.

${ }^{226}$ In the polemics conducted by the Brethren in the year 1507/1508 there is a reference to some (některé sto) hundred printed copies of the tractates Clypeus and Adversus. See above n. 124.

${ }^{227}$ Considering the Bohemian Catholic nobility of that time led by Albrecht of Kolovraty and his activities directed against the Unity of Brethen in 1503 Sokol, "Vavřinec Krasonický," 67-70. Molnár, "Protivaldenská polemika," 159, avoided (as already mentioned) identifying the prominent members of the Bohemian and Moravian Catholic nobility, who might have been able to enter into contact with Institoris and collaborate with him. Out of the supporters of the anti-Brethren Catholic publishing, Molnár lists only the later Olomouc provost Jindřich Kuna of Kunštát (1495-1553), who paid for the complete publication of the anti-Brethren treatises and tractates by A. Käsenbrot and J. Ziegler, which was printed in 1512 in Leipzig by the local typographer Melchior Lotter the older - Molnár, "Protivaldenská polemika," 160, cf. also Truhlár, Humanismus, 113. - Pope Alexander VI communicated about the heretics with the then head of the Moravian government, land governor of the Margravate of Moravia Jan Meziř́čský of Lomnice (1450-1515, land governor 1496-1515) - see in more detail above n. 83. Cf. also Winter, Život církevní, vol. I, 34.

${ }^{228}$ Molnár, "Protivaldenská polemika," 159.

${ }^{229}$ Cf. Hlobil, "Nejstarší olomoucké knižní dřevořezy," 351, n. 106.

${ }^{230}$ See above n. 227.

${ }^{231}$ Cf. above n. 227.
} 
It could not be by mere chance that Institoris, soon after his arrival in Olomouc, became friends with the Catholic prelates and at the same time humanists from the circle created in 1490 s at the court of King Vladislaus Jagiello in Buda, ${ }^{232}$ above all with Augustin Käsenbrot. This seeming paradox was due to the fact that Institoris found among these personalities his most solid and relatively most powerful ideological supporters. This was so in spite of differences in theoretical approaches and in the manner of dealing with a range of questions. Both sides were after all aware of these and referred to them quite openly. Institoris thus also took part, although somewhat mechanically and in no organic way, but not passively, in the initial phase of the development of humanistic Olomouc and became for several years its rather characteristic and from many points of view a part which could not be overlooked. ${ }^{233}$ Olomouc became an important centre of communication at the turn of the sixteenth century, and that at least in the Central European context. There is no doubt that Institoris took part in establishing the communications of Olomouc predominantly with Italy of the day and to somewhat lesser degree with the Holy Roman Empire, also participating in the transfer of a range of knowledge and information, which were the content of this already somewhat mass mediated communication. Within the framework of this communication, Institoris helped develop the transfer of knowledge about the magic arts and sorcery trials of that time, although it was marginal as to its extent and at first sight of limited importance. ${ }^{234}$

Institoris had at his disposal from his previous fields of activity which lay first of all in the south and south-west of the Holy Roman Empire and in north and central Italy, relatively numerous and varied contacts. These contacts went in some cases far beyond the scope of his own order and his activities as an inquisitor. Institoris was also able to enhance the importance of his person and of the office he held by detreatiseion of his contacts with the dignitaries, with whom he had been in a rather unfriendly relationship as in the case of the Dominican provincial Jacob Sprenger (1437-1495), referred to for a long time as the co-author of the Hammer of Witches, ${ }^{235}$ whom he obviously had never met, as it was the in case of King Vladislaus Jagiello. ${ }^{236}$ On the other hand, he must have known Pope Alexander VI, who entered into history as the most renowned of the Renaissance popes. I hold as somewhat questionable the connection made by Institoris with another, still generally known personality of his time Albrecht Dürer (1471-1528), if you like with his workshop, as argued by T. Herzig. ${ }^{237}$ Although Institoris visited Nuremberg in the first half of the 1490s or stayed there for some time and could therefore have met Dürer, the adoption of the motif of the picture shown on the title page of the Nuremberg postincunabula

\footnotetext{
232 Truhlár, Humanismus, 115-119.

${ }^{233}$ With regard to Olomouc humanists at the end of the fifteenth century and the first two decades of the sixteenth century, Petrů and Hlobil, Humanismus, 35-38 and 129-165.

${ }^{234}$ Cf. n. 133.

${ }^{235}$ Kramer (Institoris), Der Hexenhammer, 37-40. Cf. Jerouschek, "Heinrich Institoris," 122.

${ }^{236} \mathrm{Cf}$. above notes 103 and 104.

${ }^{237}$ Herzig, Christ, 230, 237-238 and 284, Fig. 3.
} 
Spiritualium into the Olomouc print of Stigmifere, could have been arranged in another way and by another person, e.g. by Konrad Baumgarten. ${ }^{238}$

There has recently repeatedly appeared in literature an opinion according to which the relationship between Institoris and the collegiate provost Käsenbrot was marked by contempt. Käsenbrot supposedly even derided the ageing inquisitor for his inefficient scholastic learning. ${ }^{239}$ This opinion is only based, however, on the distance taken by Käsenbrot from scholastic learning in his Tractatus from the year 1500 and from the topos of humility in Institoris' dedicaton of Clypeus to Bishop Thurzo concerning the fact that the tractate in question had been written in a the less refined language of scholastic theology (morem scolasticum ${ }^{249}$ ), and that the author was conscious of the inadequacy of his work and that the addressee surpassed him in learning. ${ }^{241}$ The adduced topoi, namely those about the scholastic language, are interpreted as a response to the alleged derision on the part of Käsenbrot. ${ }^{242}$ The Olomouc provost made, in my opinion, only a general statement about the inadequacy of scholastic argumentation as a means of fighting against heresy. ${ }^{243}$ Moreover, Käsenbrot could obviously have known at the time of the writing of the Tractatus at most Institoris' sermons delivered in Olomouc. I hold that Institoris maintained, during all the time of his activities in Olomouc, at least professional if not initially friendly relations with Käsenbrot. Käsenbrot not only stood near Bishop Thurzo, but was a valuable source of information and an important contact in the royal court in Buda. It was not by chance that Käsenbrot appears beside Institoris soon after Institoris' arrival in Olomouc. The printing of the woodcut with the Institoris coat of arms in Tractatus bears no testimony of derision, but rather absolute respect being paid. ${ }^{244}$ The connecting link between them was moreover Institoris' enmity towards the Unity of Brethren. The Czech Brethren put Käsenbrot in this respect on the same level with Institoris. ${ }^{245}$

The anti-Brethren publishing activities of Institoris and namely those of Käsenbrot were, apart from the Brethren's negotiations conducted by the Bohemian Utraquists in order to achieve reconciliation with Rome, one of the impulses for the issue of the mandate of King Vladislaus against the Unity of Brethren in July 1503. The said mandate was related to Bohemian royal towns and was extended in September of the same year to Moravia as well. ${ }^{246}$ Over the following months it amounted persecution of the members of the Unity of Brethren namely in royal towns and on royal demesnes in Bohemia, which made its representatives intensify public disputes and literary apologetics. ${ }^{247}$ They began to use printing

\footnotetext{
${ }^{238}$ Cf. n. 171.

${ }^{239}$ Hlaváček, "Inkvizitor," 78-79; Hlaváček, "Apostolus," 47.

${ }^{240}$ Clypeus-print 1501, fol. 5ra.

${ }^{241}$ Der lateinische Briefwechsel, 91-96.

${ }^{242}$ Der lateinische Briefwechsel, 93.

${ }^{243}$ Nechutová and Rösslerová, "Augustinus Olomucensis," 135-136.

${ }^{244}$ Hlobil, "Nejstarší olomoucké knižní dřevořezy," 329.

${ }^{245}$ See above n. 124.

246 Sokol, "Vavřinec Krasonický," 68-69.

247 Sokol, "Vavřinec Krasonický," 68-73.
} 
for this purpose as well. ${ }^{248} \mathrm{~A}$ mandate against the Unity in Moravia was also issued at the initiative of Bishop Thurzo in 1505. ${ }^{249}$ The said mandate did not incite persecution on a greater scale. ${ }^{250}$ In 1507 a sharp mandate against the Unity of Brethren was issued by the chancellor of the Kingdom of Bohemia Albrecht of Kolovraty. ${ }^{251}$ Despite the resistance of part of the nobility, this mandate was approved by the Bohemian Assembly of the Land and inserted into the public records becoming thus the law of the Land. ${ }^{252}$ The mandate had to be in force in Moravia as well, but it was substantially mitigated through the opposition of the Moravian Estates. ${ }^{253}$ In the campaign before the issue of the mandate from 1507 an important part was also played by Käsenbrot. ${ }^{254}$ Within the context of existing religious conditions in the Czech Lands and moreover in the situation of chronic tension and threatening internal war in Bohemia in the years 1500/1502-1517, ${ }^{255}$ the aforementioned legal measures lacked efficiency. They could have considerably complicated the position of the Unity of Brethren, but were not able to dimish them.

As with the recent verification of Institoris' authorship of the treatise Stigmifere, ${ }^{256}$ the aforementioned activities and operations in Olomouc shed another somewhat different light on the infamous author of the Hammer of Witches and on the circumstances under which he acted. As in the case of the ill-success of the witch trial in Innsbruck in $1485,{ }^{257}$ his activities in Olomouc are testified to by authentic personal testimonies of the contemporaries in regard to his behaviour and psychology. Stigmifere also serves to call into question the notion based on the Hammer of Witches that Institoris had been misogynyous, excluding the reports of the members of the Unity of Brethren the notion of his being an infantile old man, as he had been characterized at the beginning of the year 1486 by the (about ten years older) Bishop of Brixen Georg Golser, ${ }^{258}$ a drunkard ${ }^{259}$ or an absolute case for psychiatric treatment. ${ }^{260}$ Institoris' operations in Olomouc testify nonetheless to the fact that he was in the last years of his life a fanatic. In spite of possible partial psychopathic

${ }^{248}$ Winter, Život cirkevni, vol. I, 55-56.

249 Sokol, Vavřinec Krasonický, 72.

250 Winter, Život cirkevní, vol. I, 57.

${ }^{251}$ Winter, Život cirkevní, vol. I, 56; Sokol, "Vavřinec Krasonický," 73.

252 Sokol, "Vavřinec Krasonický," 74.

253 Sokol, "Vavřinec Krasonický," 74.

${ }^{254}$ Sokol, "Vavřinec Krasonický," 73. Cf. also above n. 124.

255 Cf. e. g. Vladislavské zrìzení zemské, 51-83.

256 See above n. 25.

${ }^{257}$ Recently in more detail Manfred Tschaikner, "Hexen in Innsbruck? Erzherzog Sigmund, Bischof Golser und Inquisitor Heinrich Kramer (1484-1486)," Der Schlern. Monatszeitschrift für die Südtiroler Landeskunde 88, no. 7/8 (Juli/August 2014): 84-102. Cf. also Hartmann Ammann, "Der Innsbrucker Hexenprocess von 1485," Zeitschrift des Ferdinandeums für Tirol und Vorarlberg, ser. 3, vol. 34 (1890): 1-87; Kramer (Institoris), Der Hexenhammer, 58-63; Ein Fels (as n. 50).

${ }^{258}$ Cf. above n. 257.

${ }^{259}$ See above n. 79.

${ }^{260}$ Jerouschek concedes that it is out of the question that Institoris "zum bloßen Psychopathen stempeln". He states, on the other hand, (first of all on the basis of the analysis of several personal tuned expressions in the Hammer of Witches), that Institoris showed numerous and heterogenous features of psychopathy and 
features of this personality the fanaticism may be considered the main characteristic of the last, Moravian stage of his life. Was this fanatical side was marked by a ruthless and fixed orientation on preconceived aims or in contrast with a capacity to deceive, to simulate and deal amically with people, whom he considered in reality, first of all for their hatred of the Catholic church, his sworn enemies and whom he evidently even despised... Even this pretending of his must have made the Bohemian Brethren angry, ${ }^{261}$ being marked out at the same time in their public appearances by full openess and sharp sincerity. Thanks to these fanatical features of his character, Institoris has been for a number of years a peculiar and therefore not to be overlooked figure in Catholic and still predominantly German Olomouc, which stood even at that time on the threshold of an important, humanistic and Renaissance epoch in its history... ${ }^{262}$

may have been a hysterical person manifesting psychosomatic symptoms - Jerouschek, "Heinrich Kramer" (as n. 25); Kramer (Institoris), Der Hexenhammer, 80-81.

261 The view of the Czech "national" mentality comes to mind here, which is on the one hand trusting and credulous and on the other hand does not allow for the abuse of confidence and perfidy connected with it. 262 On Humanism and the Renaissance in Olomouc Petrů and Hlobil, Humanismus (as n. 149). 